\title{
Exploring the barriers to using assistive technology for individuals with chronic conditions: a meta-synthesis review
}

\section{Authors:}

Jonathan Howard a,b*, Zoe Fisher ${ }^{\mathrm{c}, \mathrm{d}}$, Andrew Kemp ${ }^{\mathrm{a}}$, Stephen Lindsay ${ }^{\mathrm{e}}$, Lorna Tasker ${ }^{\mathrm{b}}$, Jeremy Tree ${ }^{\mathrm{a}}$

${ }^{a}$ Department of Psychology, College of Human and Health Sciences, Swansea University, Swansea, United Kingdom

${ }^{b}$ Rehabilitation Engineering Unit, Swansea Bay University Health Board, Morriston Hospital, Swansea, United Kingdom

${ }^{c}$ Health and Wellbeing Academy, College of Human and Health Sciences, Swansea University, Swansea, United Kingdom

${ }^{d}$ Traumatic Brain Injury Service, Swansea Bay University Health Board, Morriston Hospital, Swansea, United Kingdom

${ }^{e}$ Department of Computer Science, College of Science, Swansea University, Swansea, United Kingdom

*Corresponding Author:

Jonathan Howard, Rehabilitation Engineering Unit, Morriston Hospital, Swansea, SA6 6NL, United Kingdom.

Email: Jonathan.Howard2@wales.nhs.uk 


\section{Abstract (250 words)}

Purpose: Assistive technology can provide a key tool to enabling independence, greater inclusion and participation in society for individuals with chronic conditions. This potential is currently not always realised due to barriers to accessing and using assistive technology. This review aims to identify all the common barriers to acquiring and using assistive technology for users with chronic conditions through a systematic meta-synthesis. This differs from other systematic reviews by applying a transdiagnostic approach to identify if barriers are common across chronic conditions.

Materials and methods: A systematic literature search of five scientific databases (PubMed, SCOPUS, PsycINFO, CINAHL and Medline) was conducted to identify relevant qualitative studies. The search was conducted in November 2019. For the identified articles, thematic content analysis was conducted and the methodological quality was evaluated using the Critical Appraisal Skills Programme (CASP) checklist for qualitative research.

Results: Forty papers met the inclusion criteria and were included in the analysis. Fifty-one descriptive themes grouped into six overarching analytical themes were identified from the studies. The analytical themes identified were: the design and function of the assistive technology, service provision, information and awareness, psychological barriers, support network and societal barriers.

Conclusions: The barriers are interconnected and common across different health conditions. More involvement in personalised care for developing strategies, adaptation of home technologies and provision of assistive technology could overcome the service provision and design barriers to assistive technology. Accessible information and providing greater awareness will be important to overcoming information, psychological and societal barriers to assistive technology.

\section{Key Words (up to 8)}

Assistive technology, usage, barriers, chronic conditions, meta-synthesis, abandonment

\section{Introduction}

Finding more effective methods to manage chronic health conditions will be key to improving the sustainability of healthcare services. Between 1990 and 2017 the global challenge of disability increased as the number of years people are living with a disability increased from 562 million to 853 million [1]. Current estimates are that one billion people (15\% of the global population) are now classified as disabled with non-communicable health conditions accounting for $80 \%$ of the global burden of disability [1,2]. The prevalence of disability is predicted to continue to rise due to an increasingly ageing population arising from increases in average global life expectancy of 4.4 years by 2040 , and an increase in chronic health conditions due to life style factors such as diabetes, cardiovascular disease and mental illness $[2,3]$. The increase in disease prevalence is predicted to double global health expenditure from US\$10 trillion in 2015 to $\$ 20$ trillion by 2040 [4]. This presents an urgent need to develop solutions that address the burden chronic conditions are posing on healthcare systems as well as an opportunity to provide more effective services to this population.

Historically, the greatest burden on the healthcare system were acute medical conditions and accordingly the 'acute medical model' became the dominant model of healthcare. However, in the 
past decade there has been an epidemiological shift whereby chronic conditions have now replaced acute medical conditions as the as leading burden of morbidity, mortality, and health care expenditure [5] but models of healthcare have not adapted to reflect this shift. As such, the acute medical model has formed the basis of how healthcare systems operate for people with chronic conditions. Inherent in the acute medical model is the assumption that: injuries and diseases can be fixed; a person can return to a pre-injury state and an individual is a passive recipient of care [6]. It assumes that health and wellbeing can be achieved through the absence of impairment. For chronic conditions the acute medical model is inadequate as the condition cannot be fixed and return to a pre-injury state is not achievable [7]. Moreover, a plethora of research shows that health and wellbeing is not simply the absence of impairment and thus the goals of the acute medical model do not apply to chronic conditions [8]. Instead, chronic conditions must be managed by implementing lifestyle changes to: enhance functional status, minimise distressing symptoms, prolong life through secondary interventions and enhance quality of life through care of the whole person [9]. The management of chronic conditions requires the individual to be an active collaborator in their own care, enabling them to effectively self-manage their own health [10]. Self-management refers "to an individual's ability to manage the symptoms, treatment, physical and psychosocial consequences and life style changes inherent in living with a chronic condition" [11]. Self-management strategies are increasingly recognised as essential for the management of chronic conditions by supporting patients to be actively involved in their own care $[12,13]$.

Services should therefore be designed to promote independent health and wellbeing rather than simply aiming to ameliorate impairment or illness. For example, our recently proposed 'GENIAL' biopsychosocial model helps understand the components needed to facilitate health and wellbeing for people living with chronic conditions. Building upon previous models, it defines wellbeing as: "positive psychological experience, which can be impacted on by positive health behaviours, and is promoted through a sense of connectedness to ourselves as individuals, as well as to the communities and environment within which we live." [7]. This framework highlights a potential role for self-sustaining cycle of positive health and wellbeing underpinned by positive psychological experiences, health behaviours, communities and environments, despite the limitations imposed by a chronic condition. In terms of service provision, the GENIAL framework suggests that in order to promote pathways to health and wellbeing for people with chronic conditions, as opposed to simply ameliorating illness, services must facilitate opportunities for positive psychological experiences, positive health behaviours and positive social relationships and community integration.

Similarly to the GENIAL model, the International Classification of Functioning Disability and Health (ICF) framework is also based on a biopsychosocial model. It defines disability as the interaction between the individual's health condition and their personal and environmental contextual factors [14]. The environmental factors are classified by: products and technology, the natural and built environment, support and relationships, attitudes and services, systems and policies whilst personal factors are recognised as an individual's motivation and self-esteem. Both GENAIL and the ICF emphasise the influence of the social and physical context within which individuals live on participation, psychological experience and capacity to engage in health behaviours. In the context of wellbeing, if an individual is not able to overcome the limitations brought about by their disability, this will likely lead to negative spirals of ill-health, distress and social isolation, further contributing to a deterioration in mental and physical health [15]. Both frameworks therefore provide useful theoretical groundwork to help understand the multitude of factors that impact on an individual's health and wellbeing, enabling more effective treatments to be prescribed to help manage chronic conditions [16]. Products and technology are one aspect of the ICF's environmental factors. The use of assistive technology to help people with chronic conditions will be the focus of this work. 
Assistive technology has great potential to address the burden of chronic conditions on individuals, families, communities and societies. Assistive technology refers to "any product either specially designed and produced or generally available, whose primary purpose is to maintain or improve an individual's functioning and independence and thereby promote their wellbeing" [17]. The benefits of using assistive technology include enhancing function and independence, improved safety, promoting social inclusion and increasing participation in education, employment and society. $[18,19]$. Assistive technology can also support the management, education, monitoring of individuals with chronic conditions, reducing the need for formal and informal care and enhancing individual health and wellbeing [20-23]. Providing the right assistive technology thus has the potential to reduce the burden of chronic conditions on the individual themselves, caregivers and the wider society [22,24-27]. With an eye on enhancing health and wellbeing in people living with chronic conditions and developing more sustainable healthcare systems, the current review will clarify the existing barriers to fully realising the potential of assistive technology using a systematic review and meta-synthesis.

A major challenge to realising the full potential of assistive technology is the poor correspondence between device utility and end user needs, often leading to assistive technology not being adopted over the long-term. It is unclear from the literature what the uptake of assistive technology is but, cited abandonment rates for people using assistive technology range between 20-70\% [28-32]. The abandonment of assistive technology can be due to both positive (e.g., improved health condition), and negative factors (e.g., poor usability design). Key issues relating to non-use of assistive technology include a lack of user involvement in the design and decision making process [30,33-35], a lack of information about products and services [36-38] and the usability of assistive technology for the user $[19,22,24,39]$. The use of assistive technology varies amongst different groups. Individuals with severe mobility and sensory limitations are more likely to use assistive technology, whilst those with mental health or cognitive conditions are less likely to use assistive technology [40]. It is unclear whether the different usage of assistive technology between different populations reflects the different needs of these group or a bias in service provision in favour of people with physical disabilities. The non-use and abandonment of assistive technology may not only hinder an individual's functional ability and their social inclusion, but also reflects a waste of public resources supplying the equipment [31]. This review will systematically explore the reasons for the abandonment of assistive technology to ensure new devices and healthcare interventions are implemented that reflect the needs of the end user to reduce the abandonment rate of assistive technology.

Previous systematic reviews identifying barriers to assistive technology use have tended to focus on specific health populations and groups: older adults, people with intellectual disabilities, spinal cord injuries, Alzheimer's, cognitive impairments, stroke [19,34,36,38,41,42]; specific types of assistive technology: mobility or devices for upper-limb rehabilitation [22,35], and specific environments such as assistive technology use in higher education [18]. However, our initial review of the literature suggested that many of the barriers to using assistive technology are common across multiple chronic conditions and devices.

The aim of the current meta-synthesis is to identify all of the potential barriers that service users with chronic conditions face when trying to access and use assistive technology by summarising the current state of the research on the barriers to the access and use of assistive technology.

An inclusive, transdiagnostic search strategy was used. Based on current literature many of the barriers to assistive technology adoption were predicted to be common across different health morbidities. This approach differs from the majority of previous work that focus on particular health 
population groups. Our GENIAL framework emphasises that people with different chronic conditions share common barriers to wellbeing: undesirable health behaviours, negative psychological experiences, social isolation and exclusion [7]. An individual's health condition is therefore one component that interacts with personal, community and environment contributions that impact on health and wellbeing. As such, there may be considerable similarities in the experience of the individual across different health populations. The advantages of this approach is that if barriers are common across multiple health conditions, transdiagnostic interventions can be implemented more efficiently and effectively by focusing on commonalities across diagnoses [43].

A systematic review by Larsson and Lidstrom (2019) encompassed multiple health conditions into their systematic review, focusing on the satisfaction of the user with the service delivery process for assistive technology [44]. The review however, did not focus on aspects related to the design and usability of the assistive technology provided, which had been identified as a barrier in other reviews $[19,22,35]$. By only focusing on the service delivery process, Larsson and Lidstrom may have omitted key reasons for the abandonment of assistive technology both prior to and after provision. The current review will expand on this to include barriers to both acquiring and using assistive technology. To ensure all aspects are considered, the present review will focus on the views of key assistive technology stakeholders including: end-users, family members, carers and healthcare professionals, across different chronic conditions. To date no work has been published aiming to identify the barriers relating to all aspects of the use and provision of assistive technology across different chronic conditions. Identifying the barriers to the use of assistive technology will severe to better understand how to help realise the enormous potential that assistive technology may have in improving the health and wellbeing of people with chronic conditions as well as reducing the burden on health and social services. It is hoped that this would will inform better service design which addresses the identified barriers to technology usage. 


\section{Methodology}

A meta-synthesis was conducted following the guidelines published by Lachal, Revah-Levy [45] and applying the structured methodological approach for systematic reviews described by the Preferred Reporting Items for Systematic Reviews and Meta-Analyses (PRISMA) guidelines [46].

\section{Search terms and Information sources}

The search strategy was developed based on two groups of search terms relating to "assistive technology" and "barriers/use". A full list of terms used is presented in Table 1. Consensus for all the search terms was reached with all the authors prior to undertaking the database searches. Boolean logic was used to combine the search terms within each group using the operator OR and between the two groups using the operator AND.

The full search terms were inputted into 5 electronic databases to identify relevant studies: PubMed, SCOPUS, PsycINFO, CINAHL and Medline. The databases where searched from the earliest available records to 4th November 2019. Studies were identified which included the terms in the title and abstract only and when full text articles in English were available.

Table 1: Full search terms used for PubMed database. Plurals were allowed by using wildcard (*)

\begin{tabular}{|c|c|}
\hline Search Group & Terms \\
\hline Assistive Technology & 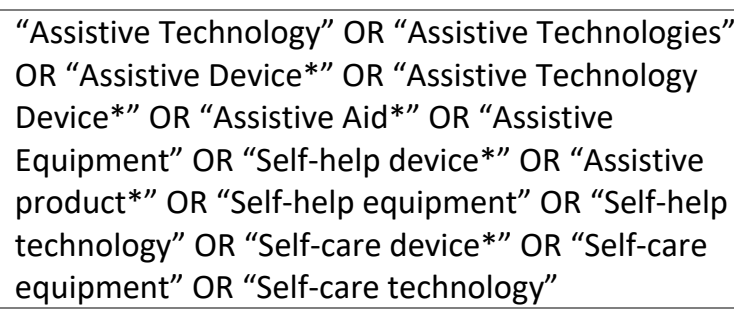 \\
\hline Barriers/use & $\begin{array}{l}\text { Barrier* OR Use OR Usage OR Failure* OR mis-use } \\
\text { OR Abandon OR Abandonment OR obstacle* OR } \\
\text { attitude* OR perception* OR acceptance }\end{array}$ \\
\hline
\end{tabular}

\section{Study Selection}

After removing duplicates, studies were selected using a multi-stage process shown in Figure 1. Using the predefined inclusion/exclusion criteria, studies were first screened by title and then by abstract to identify articles for full text reading. Articles that passed the abstract screening were then read and compared against the inclusion/exclusion criteria in Table 2. The screening criteria were developed to capture qualitative studies concerning adults with chronic conditions and the barriers they experience to assistive technology use. This included qualitative studies involving carers, family members and healthcare professionals. These stakeholders play a key role in the provision and usage of assistive technology and therefore their opinions are important when identifying barriers to assistive technology access and use. All authors agreed the inclusion/exclusion criteria prior to undertaking the search.

Table 2: Inclusion and exclusion criteria used for identifying relevant articles.

\section{Inclusion Criteria}

Exclusion criteria

Published peer reviewed journal articles

Chronic Conditions

Adult population (>18)

Empirical data

Children or teenagers

Non-empirical (review papers) 


\begin{tabular}{ll}
\hline Qualitative studies & $\begin{array}{l}\text { Quantitative, questionnaire or case studies (1-3 } \\
\text { participants) }\end{array}$ \\
\hline Included verbatim statements from subjects & Product testing of a singular product or system \\
\hline $\begin{array}{l}\text { Explores reasons for use/non-use of current AT } \\
\text { provision }\end{array}$ & $\begin{array}{l}\text { Outcome measures and physiological measures } \\
\text { related to AT }\end{array}$ \\
\hline
\end{tabular}

\section{Data extraction and analysis}

Forty studies met all the inclusion criteria. For each study, the following data was extracted: Author/s, publication year, country of origin, aim, sample population, type of AT, Table 3.

\section{Thematic analysis}

Results from the studies were combined using the three-phase process of thematic synthesis described by Thomas and Harden (2008) [45,47]. This thematic synthesis has been used in other systematic reviews $[22,36]$. Initially the first author became familiar with the studies by reading and re-reading each article. Next line-by-line coding of the findings from the studies was used to inductively generate descriptive themes. Similar themes were then grouped together and definitions created for each theme. Next, all the articles were re-read and a deductive thematic approach was used to ensure all the themes for each article had been identified. Finally, overarching analytical themes were generated and finalised through reaching consensus with a wider research group of academics and healthcare professionals with backgrounds in psychology, engineering and computer science.

\section{Evaluation of studies}

The level of evidence in each study was evaluated using the Critical Appraisal Skills Program (CASP) checklist for qualitative research [48]. The assessment was weighted using a three-point scale for each of the 10 criteria, $(0=$ not met, $1=$ partially met and $2=$ totally met) to give a total score for each articles out of 20. This method of applying a weighted scale is recommended by the Cochrane Collaboration [45].

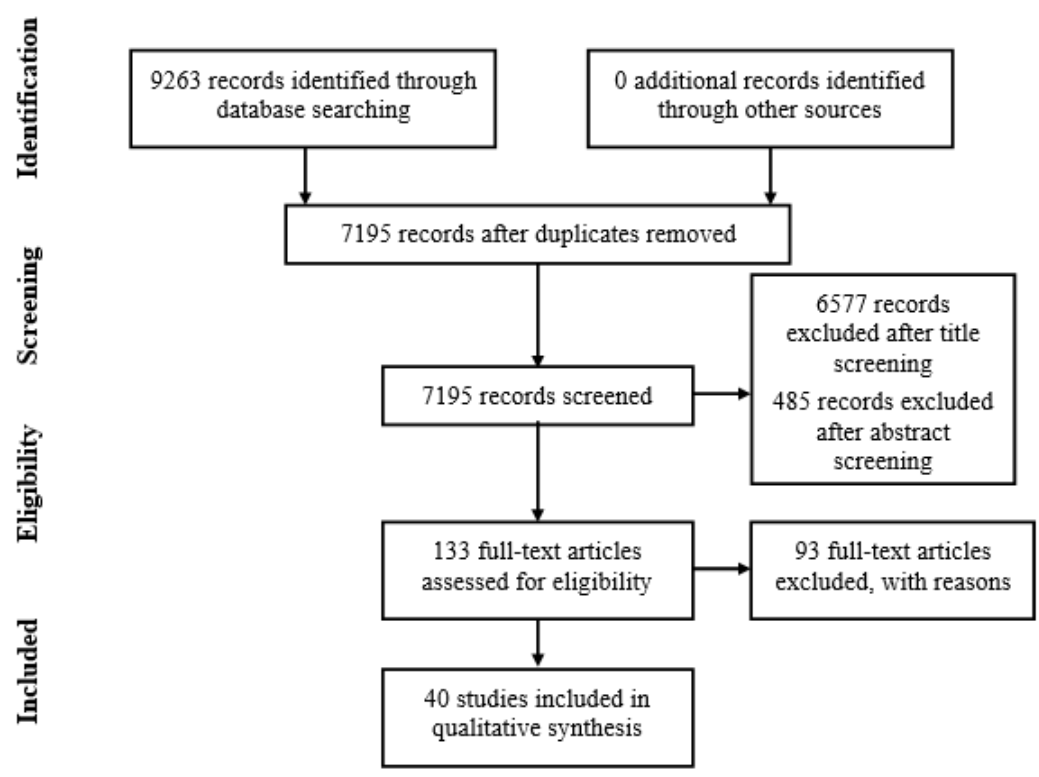

Figure 1: PRISMA flow diagram showing the number of articles identified and screened for eligibility during the metasynthesis [46]. 
Table 3: Summary information of articles included in the meta-synthesis

\begin{tabular}{|c|c|c|c|c|c|c|}
\hline $\begin{array}{c}\text { Author (year) } \\
\text { [ref] }\end{array}$ & Country & Aim & $\begin{array}{c}\text { Sample } \\
\text { characteristics }\end{array}$ & $\begin{array}{c}\text { Types of assistive } \\
\text { technology }\end{array}$ & Identified barriers & $\begin{array}{l}\text { CASP } \\
\text { Score }\end{array}$ \\
\hline $\begin{array}{l}\text { Adolfsson, } \\
\text { Lindstedt [49] }\end{array}$ & Sweden & $\begin{array}{l}\text { Explore how adults with cognitive disabilities } \\
\text { perceive the influence of environmental factors } \\
\text { on the use of electronic planning devices }\end{array}$ & $\begin{array}{l}\text { Adults with cognitive } \\
\text { disabilities } \\
(n=12)\end{array}$ & $\begin{array}{l}\text { Electronic planning } \\
\text { devices }\end{array}$ & $\begin{array}{l}\text { Design and function } \\
\text { Awareness \& information } \\
\text { Service Provision } \\
\text { Attitudes } \\
\text { Financial } \\
\text { Societal barriers }\end{array}$ & 17 \\
\hline $\begin{array}{l}\text { Andregard and } \\
\text { Magnusson [50] }\end{array}$ & Sierra Leone & $\begin{array}{l}\text { Describe the experience of using and attitudes } \\
\text { towards orthotic and prosthetics devices in } \\
\text { Sierra Leone from the perspective of people } \\
\text { with poliomyelitis and amputations }\end{array}$ & $\begin{array}{l}\text { Polio or amputations } \\
(n=12)\end{array}$ & Mobility aids & $\begin{array}{l}\text { Design and function } \\
\text { Service Provision } \\
\text { Attitudes } \\
\text { Financial } \\
\text { Societal barriers }\end{array}$ & 14 \\
\hline Asghar, Cang [51] & Pakistan & $\begin{array}{l}\text { Investigate the advantages, limitations, } \\
\text { functions and impacts of assistive technology for } \\
\text { people with dementia and explore future } \\
\text { requirements for assistive technology }\end{array}$ & $\begin{array}{l}\text { Dementia } \\
(\mathrm{n}=20)\end{array}$ & Mixed & $\begin{array}{l}\text { Design and function } \\
\text { Awareness \& information } \\
\text { Service Provision }\end{array}$ & 17 \\
\hline $\begin{array}{l}\text { Baldwin, Powell } \\
\text { [52] }\end{array}$ & UK & $\begin{array}{l}\text { Expand on the current understanding of factors } \\
\text { that influence the use of compensatory aids and } \\
\text { strategies for people with acquired brain injuries }\end{array}$ & $\begin{array}{l}\text { Acquired Brain Injury } \\
(n=8)\end{array}$ & Memory aids & $\begin{array}{l}\text { Design and function } \\
\text { Service Provision } \\
\text { Attitudes }\end{array}$ & 14 \\
\hline $\begin{array}{l}\text { Boger, Quraishi } \\
\text { [53] }\end{array}$ & Canada & $\begin{array}{l}\text { Investigate what assistive technology is in use, } \\
\text { what factors affect use and gaps in current AT } \\
\text { use to support the daily occupations of } \\
\text { community-dwelling older adults with dementia } \\
\text { and family caregivers }\end{array}$ & $\begin{array}{l}\text { Dementia } \\
\text { ( } n=13 ; 3 \text { family caregivers } \\
\text { and } 10 \text { occupational } \\
\text { therapists) }\end{array}$ & Mixed & $\begin{array}{l}\text { Design and function } \\
\text { Awareness \& information } \\
\text { Service Provision } \\
\text { Attitudes } \\
\text { Financial }\end{array}$ & 14 \\
\hline $\begin{array}{l}\text { Boot, MacLachlan } \\
{[54]}\end{array}$ & Ireland & $\begin{array}{l}\text { Understand the barriers and facilitators to } \\
\text { effectively access and use essential AT for } \\
\text { people with intellectual disability }\end{array}$ & $\begin{array}{l}\text { Intellectual disability } \\
\text { ( } \mathrm{n}=30 ; 15 \text { with intellectual } \\
\text { disability and } 15 \text { assistive } \\
\text { technology providers) }\end{array}$ & Mixed & $\begin{array}{l}\text { Design and function } \\
\text { Awareness \& information } \\
\text { Service Provision } \\
\text { Attitudes } \\
\text { Financial } \\
\text { Societal barriers }\end{array}$ & 15 \\
\hline $\begin{array}{l}\text { Cook, Randhawa } \\
\text { [55] }\end{array}$ & UK & $\begin{array}{l}\text { Explore the factors that impact patients' } \\
\text { decisions to initially adopt and continually } \\
\text { engage with telehealth and telecare applications }\end{array}$ & $\begin{array}{l}\text { Mixed } \\
\text { ( } n=40 ; 28 \text { users and } 12 \\
\text { non-users) }\end{array}$ & Telehealth and telecare & $\begin{array}{l}\text { Design and function } \\
\text { Awareness \& information } \\
\text { Service Provision } \\
\text { Attitudes }\end{array}$ & 17 \\
\hline
\end{tabular}




\begin{tabular}{|c|c|c|c|c|c|c|}
\hline $\begin{array}{l}\text { Creemers, Beelen } \\
\text { [56] }\end{array}$ & Netherlands & $\begin{array}{l}\text { Explore experiences of patients with } \\
\text { amyotrophic lateral sclerosis during the } \\
\text { application and provision process of assistive } \\
\text { technology }\end{array}$ & $\begin{array}{l}\text { Amyotrophic Lateral } \\
\text { Sclerosis } \\
(n=179)\end{array}$ & Mixed & $\begin{array}{l}\text { Awareness \& information } \\
\text { Service Provision } \\
\text { Financial }\end{array}$ & 9 \\
\hline Darcy, Maxwell [57] & Australia & $\begin{array}{l}\text { Explore the perceptions of a mobile technology } \\
\text { platform as experienced by people with } \\
\text { disability, their significant others and service } \\
\text { providers }\end{array}$ & $\begin{array}{l}\text { Mixed } \\
\text { ( } n=15 ; 10 \text { intellectual, } 4 \\
\text { physical and } 1 \text { cognitive } \\
\text { disability) }\end{array}$ & $\begin{array}{l}\text { Information and } \\
\text { communications } \\
\text { technology }\end{array}$ & $\begin{array}{l}\text { Design and function } \\
\text { Awareness \& information } \\
\text { Service Provision } \\
\text { Attitudes }\end{array}$ & 14 \\
\hline $\begin{array}{l}\text { Demain, Burridge } \\
\text { [58] }\end{array}$ & UK & $\begin{array}{l}\text { Identify the barriers and facilitators to the use of } \\
\text { upper-limb rehabilitation and assistive } \\
\text { technology to support stroke self-management }\end{array}$ & $\begin{array}{l}\text { Stroke } \\
(n=21)\end{array}$ & $\begin{array}{l}\text { Upper limb } \\
\text { rehabilitation aids }\end{array}$ & $\begin{array}{l}\text { Design and function } \\
\text { Awareness \& information } \\
\text { Service Provision } \\
\text { Attitudes } \\
\text { Financial }\end{array}$ & 17 \\
\hline $\begin{array}{l}\text { Dorjbal, Prodinger } \\
\text { [59] }\end{array}$ & Mongolia & $\begin{array}{l}\text { Identify environmental barriers and their } \\
\text { impacts on daily lives as perceived by individuals } \\
\text { living with Spinal Cord Injury in Mongolia }\end{array}$ & $\begin{array}{l}\text { Spinal Cord Injury (SCI) } \\
(\mathrm{n}=16)\end{array}$ & Mixed & $\begin{array}{l}\text { Design and function } \\
\text { Awareness \& information } \\
\text { Service Provision } \\
\text { Attitudes } \\
\text { Financial } \\
\text { Societal barriers } \\
\end{array}$ & 14 \\
\hline $\begin{array}{l}\text { Durham, Sychareun } \\
\text { [60] }\end{array}$ & $\begin{array}{l}\text { Lao People's } \\
\text { Democratic } \\
\text { Republic }\end{array}$ & $\begin{array}{l}\text { Investigate client satisfaction with their } \\
\text { prosthetic and orthotic devices and services in } \\
\text { Lao }\end{array}$ & $\begin{array}{l}\text { Mixed } \\
(n=34)\end{array}$ & $\begin{array}{l}\text { Prosthetics and } \\
\text { orthotics }\end{array}$ & $\begin{array}{l}\text { Design and function } \\
\text { Awareness \& information } \\
\text { Service Provision } \\
\text { Financial }\end{array}$ & 13 \\
\hline $\begin{array}{l}\text { Elnady, Mortenson } \\
\text { [61] }\end{array}$ & Canada & $\begin{array}{l}\text { Describe user's perceptions of assistive } \\
\text { technology for the upper extremities, } \\
\text { investigate if there is a need to develop new } \\
\text { devices and identify factors that would limit the } \\
\text { utilisation of any new devices }\end{array}$ & $\begin{array}{l}\text { Stroke } \\
\text { ( } \mathrm{n}=18 ; 8 \text { with stroke and } 8 \\
\text { healthcare professionals) }\end{array}$ & $\begin{array}{l}\text { Upper limb } \\
\text { rehabilitation }\end{array}$ & $\begin{array}{l}\text { Design and function } \\
\text { Awareness \& information } \\
\text { Service Provision } \\
\text { Attitudes } \\
\text { Financial }\end{array}$ & 19 \\
\hline $\begin{array}{l}\text { Fager and Burnfield } \\
\text { [62] }\end{array}$ & USA & $\begin{array}{l}\text { Describe individual perceptions of technology } \\
\text { used for environment controls and therapeutic } \\
\text { exercise during in-patient rehabilitation }\end{array}$ & $\begin{array}{l}\text { Mixed } \\
\text { ( } n=10 ; 5 \text { with spinal cord } \\
\text { injury, } 2 \text { with stroke, } 1 \text { with } \\
\text { traumatic brain injury, } 1\end{array}$ & $\begin{array}{l}\text { Environmental controls } \\
\& \text { Augmentative and } \\
\text { alternative } \\
\text { communication aids }\end{array}$ & $\begin{array}{l}\text { Design and function } \\
\text { Awareness \& information } \\
\text { Service Provision }\end{array}$ & 12 \\
\hline
\end{tabular}




\begin{tabular}{|c|c|c|c|c|c|c|}
\hline & & & $\begin{array}{l}\text { Scleroderma and } 1 \\
\text { pulmonary insufficiency) }\end{array}$ & & & \\
\hline Fomiatti, Moir [63] & Australia & $\begin{array}{l}\text { Explore the lived experience of individuals who } \\
\text { used a scooter to compensate for limited } \\
\text { mobility and explore the benefits, barriers and } \\
\text { enablers to inclusion and social participation }\end{array}$ & $\begin{array}{l}\text { Mobility limitation } \\
(\mathrm{n}=14)\end{array}$ & Mobility Scooter & $\begin{array}{l}\text { Design and function } \\
\text { Awareness \& information } \\
\text { Service Provision } \\
\text { Attitudes } \\
\text { Societal barriers }\end{array}$ & 15 \\
\hline $\begin{array}{l}\text { Gelinas-Bronsard, } \\
\text { Mortenson [64] }\end{array}$ & Canada & $\begin{array}{l}\text { Identify the needs of older adults and family } \\
\text { caregivers relating to assistive technology } \\
\text { procurements and how to offer remote support } \\
\text { through an internet-based intervention }\end{array}$ & $\begin{array}{l}\text { Mixed } \\
\text { ( } n=30 ; 5 \text { assistive } \\
\text { technology users, } 5 \text { carers, } \\
5 \text { healthcare professionals, } \\
5 \text { decision makers, } 5 \\
\text { community partners, } 5 \\
\text { researchers) }\end{array}$ & Mixed & $\begin{array}{l}\text { Design and function } \\
\text { Awareness \& information } \\
\text { Service Provision } \\
\text { Financial }\end{array}$ & 19 \\
\hline Gerber [65] & USA & $\begin{array}{l}\text { Identify the benefits of and barriers to computer } \\
\text { use for people who are visually impaired }\end{array}$ & $\begin{array}{l}\text { Visual impairment } \\
(n=41)\end{array}$ & Computer access & $\begin{array}{l}\text { Design and function } \\
\text { Awareness \& information } \\
\text { Service Provision } \\
\text { Attitudes } \\
\text { Financial }\end{array}$ & 7 \\
\hline $\begin{array}{l}\text { Gibson, Dickinson } \\
\text { [66] }\end{array}$ & UK & $\begin{array}{l}\text { Explore how people with dementia and their } \\
\text { families use assistive technology in their } \\
\text { everyday lives }\end{array}$ & $\begin{array}{l}\text { Dementia } \\
\text { ( } n=39 ; 13 \text { with dementia, } \\
18 \text { family carers and } 8 \\
\text { formal carers) }\end{array}$ & Mixed & $\begin{array}{l}\text { Design and function } \\
\text { Awareness \& information } \\
\text { Service Provision } \\
\text { Attitudes } \\
\text { Financial }\end{array}$ & 13 \\
\hline $\begin{array}{l}\text { Gitlin, Luborsky } \\
\text { [67] }\end{array}$ & USA & $\begin{array}{l}\text { Examine the personal meanings associated with } \\
\text { first-time encounters with device use following } \\
\text { the acute onset of disease }\end{array}$ & $\begin{array}{l}\text { Stroke } \\
(n=103)\end{array}$ & Mixed & $\begin{array}{l}\text { Design and function } \\
\text { Awareness \& information } \\
\text { Service Provision } \\
\text { Attitudes }\end{array}$ & 13 \\
\hline $\begin{array}{l}\text { Hedberg- } \\
\text { Kristensson, Ivanoff } \\
{[68]}\end{array}$ & Sweden & $\begin{array}{l}\text { Investigate older persons' experiences of using } \\
\text { mobility devices }\end{array}$ & $\begin{array}{l}\text { Mobility impairments } \\
(\mathrm{n}=22)\end{array}$ & Mobility device & $\begin{array}{l}\text { Design and function } \\
\text { Awareness \& information } \\
\text { Service Provision } \\
\text { Attitudes } \\
\text { Societal barriers }\end{array}$ & 16 \\
\hline Holthe, Jentoft [69] & Norway & $\begin{array}{l}\text { Examine the role of and the experiences that } \\
\text { family carers of people with young onset } \\
\text { dementia have concerning the use of assistive } \\
\text { technology to support everyday life }\end{array}$ & $\begin{array}{l}\text { Dementia (Young Onset) } \\
\text { ( } n=13, \text { carers) }\end{array}$ & Mixed & $\begin{array}{l}\text { Design and function } \\
\text { Awareness \& information } \\
\text { Service Provision }\end{array}$ & 17 \\
\hline
\end{tabular}




\begin{tabular}{|c|c|c|c|c|c|c|}
\hline Holz, Bennett [70] & Canada & $\begin{array}{l}\text { Explore individual perceptions of using rollators } \\
\text { to identify factors that may inform ways in } \\
\text { which clinicians can promote optimal usage of } \\
\text { rollators }\end{array}$ & $\begin{array}{l}\text { Chronic obstructive } \\
\text { pulmonary disease } \\
(\mathrm{n}=12)\end{array}$ & Rollators & $\begin{array}{l}\text { Design and function } \\
\text { Awareness \& information } \\
\text { Service Provision } \\
\text { Attitudes } \\
\text { Societal barriers }\end{array}$ & 12 \\
\hline Jamieson, Jack [71] & UK & $\begin{array}{l}\text { Investigate the barriers and solutions to the } \\
\text { performance of meaning activities for people } \\
\text { receiving rehabilitation for brain injuries }\end{array}$ & $\begin{array}{l}\text { Acquired Brain Injury (ABI) } \\
\text { ( } n=24,9 \text { with } A B I, 12 \\
\text { formal carers and } 3 \text { family } \\
\text { carers) }\end{array}$ & Mixed & $\begin{array}{l}\text { Design and function } \\
\text { Awareness \& information } \\
\text { Service Provision } \\
\text { Attitudes } \\
\text { Financial } \\
\end{array}$ & 11 \\
\hline Lenker, Harris [72] & USA & $\begin{array}{l}\text { Explore device outcomes that are most valued } \\
\text { by assistive technology users and identify } \\
\text { elements in the device acquisition process that } \\
\text { affect outcomes }\end{array}$ & $\begin{array}{l}\text { Mixed } \\
\text { ( } n=24 ; \text { spinal cord injury, } \\
\text { cerebral palsy, hearing } \\
\text { impairments, blindness, } \\
\text { physical disability, vision } \\
\text { loss and other } \\
\text { developmental disabilities) }\end{array}$ & Mixed & $\begin{array}{l}\text { Design and function } \\
\text { Awareness \& information } \\
\text { Service Provision } \\
\text { Financial }\end{array}$ & 14 \\
\hline $\begin{array}{l}\text { Mann and Tomita } \\
\text { [73] }\end{array}$ & USA & $\begin{array}{l}\text { Examine how satisfied people are with assistive } \\
\text { devices they own, what problems they have } \\
\text { with them and what suggestions for new } \\
\text { devices they have }\end{array}$ & $\begin{array}{l}\text { Mixed (frail elders) } \\
(n=508)\end{array}$ & mixed & $\begin{array}{l}\text { Design and function } \\
\text { Awareness \& information } \\
\text { Service Provision } \\
\text { Attitudes } \\
\text { Financial } \\
\text { Societal barriers }\end{array}$ & 8 \\
\hline $\begin{array}{l}\text { McGrath and Astell } \\
\text { [74] }\end{array}$ & Canada & $\begin{array}{l}\text { Explore the decision-making processes of older } \\
\text { adults with age related vision loss relating to } \\
\text { acquisition and use of assistive technology }\end{array}$ & $\begin{array}{l}\text { Age related vision loss } \\
(n=10)\end{array}$ & Mixed & $\begin{array}{l}\text { Design and function } \\
\text { Awareness \& information } \\
\text { Service Provision } \\
\text { Attitudes } \\
\text { Financial } \\
\text { Societal barriers } \\
\end{array}$ & 12 \\
\hline $\begin{array}{l}\text { Mortenson, } \\
\text { Pysklywec [75] }\end{array}$ & Canada & $\begin{array}{l}\text { Explore caregivers experience with assistive } \\
\text { technology to facilitate care recipients' } \\
\text { independence and understand the experience of } \\
\text { caregivers in identifying and selecting assistive } \\
\text { technology }\end{array}$ & $\begin{array}{l}\text { Mobility limitation } \\
\text { ( } n=27 \text {, carers) }\end{array}$ & Mixed & $\begin{array}{l}\text { Service Provision } \\
\text { Financial }\end{array}$ & 14 \\
\hline Myburg, Allan [76] & Australia & $\begin{array}{l}\text { Investigate the prescription and utilisation of } \\
\text { environmental control systems from the } \\
\text { consumer perspective. }\end{array}$ & $\begin{array}{l}\text { Spinal Cord Injury } \\
(n=15)\end{array}$ & $\begin{array}{l}\text { Environmental control } \\
\text { systems (ECS) }\end{array}$ & $\begin{array}{l}\text { Design and function } \\
\text { Awareness \& information } \\
\text { Service Provision }\end{array}$ & 16 \\
\hline
\end{tabular}




\begin{tabular}{|c|c|c|c|c|c|c|}
\hline $\begin{array}{l}\text { Newton, Dickinson } \\
\text { [37] }\end{array}$ & UK & $\begin{array}{l}\text { Explore the views and experiences of general } \\
\text { practitioners, people with dementia and family } \\
\text { carers on their knowledge and experience of } \\
\text { accessing information about and use of assistive } \\
\text { technology in practise }\end{array}$ & $\begin{array}{l}\text { Dementia } \\
\text { ( } n=56 ; 13 \text { with dementia, } \\
17 \text { GPs and } 26 \text { carers) }\end{array}$ & Mixed & $\begin{array}{l}\text { Awareness \& information } \\
\text { Service Provision } \\
\text { Financial } \\
\text { Societal barriers }\end{array}$ & 15 \\
\hline $\begin{array}{l}\text { Okonji and } \\
\text { Ogwezzy [77] }\end{array}$ & Nigeria & $\begin{array}{l}\text { Explore barriers to adoption and access to } \\
\text { assistive technology among visually impaired } \\
\text { people in Nigeria }\end{array}$ & $\begin{array}{l}\text { Blind and Visually impaired } \\
(n=20)\end{array}$ & Visual aids & $\begin{array}{l}\text { Design and function } \\
\text { Awareness \& information } \\
\text { Service Provision } \\
\text { Attitudes } \\
\text { Financial } \\
\text { Societal barriers }\end{array}$ & 14 \\
\hline $\begin{array}{l}\text { Orellano-Colon, } \\
\text { Mann [78] }\end{array}$ & Puerto Rico & $\begin{array}{l}\text { Identify barriers to successful use of assistive } \\
\text { technology from the perspective of community- } \\
\text { dwelling older Hispanics with functional } \\
\text { limitations living in Puerto Rico }\end{array}$ & $\begin{array}{l}\text { Mixed } \\
\text { ( } \mathrm{n}=60 \text { musculoskeletal, } \\
\text { hypertension, diabetes, } \\
\text { visual, respiratory, cardiac, } \\
\text { overweight) }\end{array}$ & Mixed & $\begin{array}{l}\text { Design and function } \\
\text { Awareness \& information } \\
\text { Service Provision } \\
\text { Attitudes } \\
\text { Financial } \\
\text { Societal barriers }\end{array}$ & 16 \\
\hline $\begin{array}{l}\text { Oyesanya, } \\
\text { Thompson [79] }\end{array}$ & USA & $\begin{array}{l}\text { Investigate the views of technology from the } \\
\text { perspective of individuals with traumatic brain } \\
\text { injuries to address their health, wellness and } \\
\text { safety concerns }\end{array}$ & $\begin{array}{l}\text { Traumatic Brain Injury (TBI) } \\
\text { ( } \mathrm{n}=27 ; 15 \text { with TBI, } 12 \\
\text { carers) }\end{array}$ & Mixed & $\begin{array}{l}\text { Design and function } \\
\text { Attitudes } \\
\text { Financial }\end{array}$ & 18 \\
\hline Pereira, Pena [80] & Brazil & $\begin{array}{l}\text { Identify the main facilitators and barriers in the } \\
\text { use of alternative and augmentative } \\
\text { communication systems by adults diagnosed } \\
\text { with aphasia }\end{array}$ & $\begin{array}{l}\text { Aphasia } \\
\text { ( } \mathrm{n}=3, \text { healthcare } \\
\text { professionals) }\end{array}$ & $\begin{array}{l}\text { Alternative and } \\
\text { augmentative } \\
\text { communication }\end{array}$ & $\begin{array}{l}\text { Design and function } \\
\text { Service Provision } \\
\text { Financial }\end{array}$ & 13 \\
\hline Ravneberg [81] & Norway & $\begin{array}{l}\text { Explore the usability of and reasons for the } \\
\text { abandonment of assistive technology }\end{array}$ & $\begin{array}{l}\text { Hearing loss } \\
\text { ( } n=12 ; 5 \text { with hearing loss, } \\
7 \text { service providers) }\end{array}$ & $\begin{array}{l}\text { Hearing aids and } \\
\text { signalling devices }\end{array}$ & $\begin{array}{l}\text { Design and function } \\
\text { Awareness \& information } \\
\text { Service Provision } \\
\text { Attitudes } \\
\text { Financial }\end{array}$ & 6 \\
\hline $\begin{array}{l}\text { Riikonen, } \\
\text { Paavilainen [82] }\end{array}$ & Finland & $\begin{array}{l}\text { Explore factors that facilitate the use of } \\
\text { technology in the daily life of home-living people } \\
\text { with dementia }\end{array}$ & $\begin{array}{l}\text { Dementia } \\
(n=25)\end{array}$ & Mixed & $\begin{array}{l}\text { Design and function } \\
\text { Awareness \& information } \\
\text { Service Provision } \\
\text { Attitudes }\end{array}$ & 15 \\
\hline $\begin{array}{l}\text { Seymour, Geiger } \\
\text { [83] }\end{array}$ & Uganda & $\begin{array}{l}\text { Determine what community-based } \\
\text { rehabilitation workers in Uganda perceive as the } \\
\text { challenges to wheelchair provision and use, } \\
\text { factors contributing to these challenges and } \\
\text { what facilitators they need to overcome the } \\
\text { challenges }\end{array}$ & $\begin{array}{l}\text { Mobility } \\
\text { ( } n=21 \text {, community-based } \\
\text { rehabilitation workers) }\end{array}$ & Wheelchairs & $\begin{array}{l}\text { Design and function } \\
\text { Awareness \& information } \\
\text { Service Provision } \\
\text { Attitudes } \\
\text { Financial } \\
\text { Societal barriers }\end{array}$ & 15 \\
\hline
\end{tabular}




\begin{tabular}{|c|c|c|c|c|c|c|}
\hline Smith, Quine [84] & Australia & $\begin{array}{l}\text { Explore factors affecting the acceptability and } \\
\text { use of assistive technology by older people }\end{array}$ & $\begin{array}{l}\text { Mixed } \\
\text { ( } \mathrm{n}=40 \text {; stroke, fractures, } \\
\text { arthritis and motor } \\
\text { neurone disease) } \\
25 \text { focus group and } 15 \\
\text { interviews) }\end{array}$ & Mixed & $\begin{array}{l}\text { Design and function } \\
\text { Awareness \& information } \\
\text { Service Provision } \\
\text { Attitudes } \\
\text { Financial }\end{array}$ & 15 \\
\hline $\begin{array}{l}\text { Taherian and } \\
\text { Davies [85] }\end{array}$ & New Zealand & $\begin{array}{l}\text { Understand the experiences and perspectives of } \\
\text { assistive technology from different stakeholders } \\
\text { involved in assistive technology provision in } \\
\text { New Zealand }\end{array}$ & $\begin{array}{l}\text { Cerebral Palsy (CP) } \\
\text { ( } n=13 ; 5 \text { with CP, } 3 \text { carers } \\
\text { and } 5 \text { healthcare } \\
\text { professionals) }\end{array}$ & Mixed & $\begin{array}{l}\text { Design and function } \\
\text { Awareness \& information } \\
\text { Service Provision } \\
\text { Attitudes } \\
\text { Financial }\end{array}$ & 15 \\
\hline $\begin{array}{l}\text { Van Den Heuvel, } \\
\text { Jowitt [86] }\end{array}$ & UK & $\begin{array}{l}\text { Explore the barriers to the uptake of and the } \\
\text { unmet needs for assistive technology for } \\
\text { dementia }\end{array}$ & $\begin{array}{l}\text { Dementia } \\
\text { ( } n=12, \text { carers })\end{array}$ & Mixed & $\begin{array}{l}\text { Awareness \& information } \\
\text { Attitudes }\end{array}$ & 11 \\
\hline $\begin{array}{l}\text { Weerasinghe, } \\
\text { Fonseka [87] }\end{array}$ & Sri Lanka & $\begin{array}{l}\text { Describe the barriers in using assistive } \\
\text { technology among community-dwelling } \\
\text { residents with unilateral lower limb disabilities } \\
\text { in central Sri Lanka }\end{array}$ & $\begin{array}{l}\text { Amputees (lower limb) } \\
(n=12)\end{array}$ & Prosthetics & $\begin{array}{l}\text { Design and function } \\
\text { Awareness \& information } \\
\text { Service Provision } \\
\text { Attitudes } \\
\text { Financial } \\
\text { Societal barriers }\end{array}$ & 15 \\
\hline
\end{tabular}




\section{Results}

\section{Article characteristics and level of evidence}

9263 articles were identified through database searching of which 7195 remained once duplicates were removed, Figure 1. 6577 studies were excluded during title screening and a further 485 excluded after abstract reading. 133 articles were read in full from which 93 were excluded. A total of 40 articles were included in the analysis and are summarised in Table 3.

The majority of the studies were undertaken in European $(n=14)$ or North American $(n=12)$ countries with the remainder conducted in Australasia $(n=5)$, Asia $(n=4)$, Africa $(n=3)$ and South America $(n=2)$. A wide range of health conditions were covered in the articles: dementia $(n=7)$, mobility impairments $(n=7)$, hearing and visual impairments $(n=4)$, stroke $(n=3)$, acquired/traumatic brain injuries ( $n=3)$, spinal cord injury $(n=2)$, cerebral palsy $(n=1)$, cognitive disabilities $(n=1)$, intellectual disability $(n=1)$, chronic obstructive pulmonary disease $(n=1)$, amyotrophic lateral sclerosis $(n=1)$, aphasia $(n=1)$ and studies recruiting a mix of health conditions $(n=8)$. A mix of different assistive technologies are reported on including mobility aids, environmental controls, alternative and augmentative communication, telehealth and telecare and memory/planning aids.

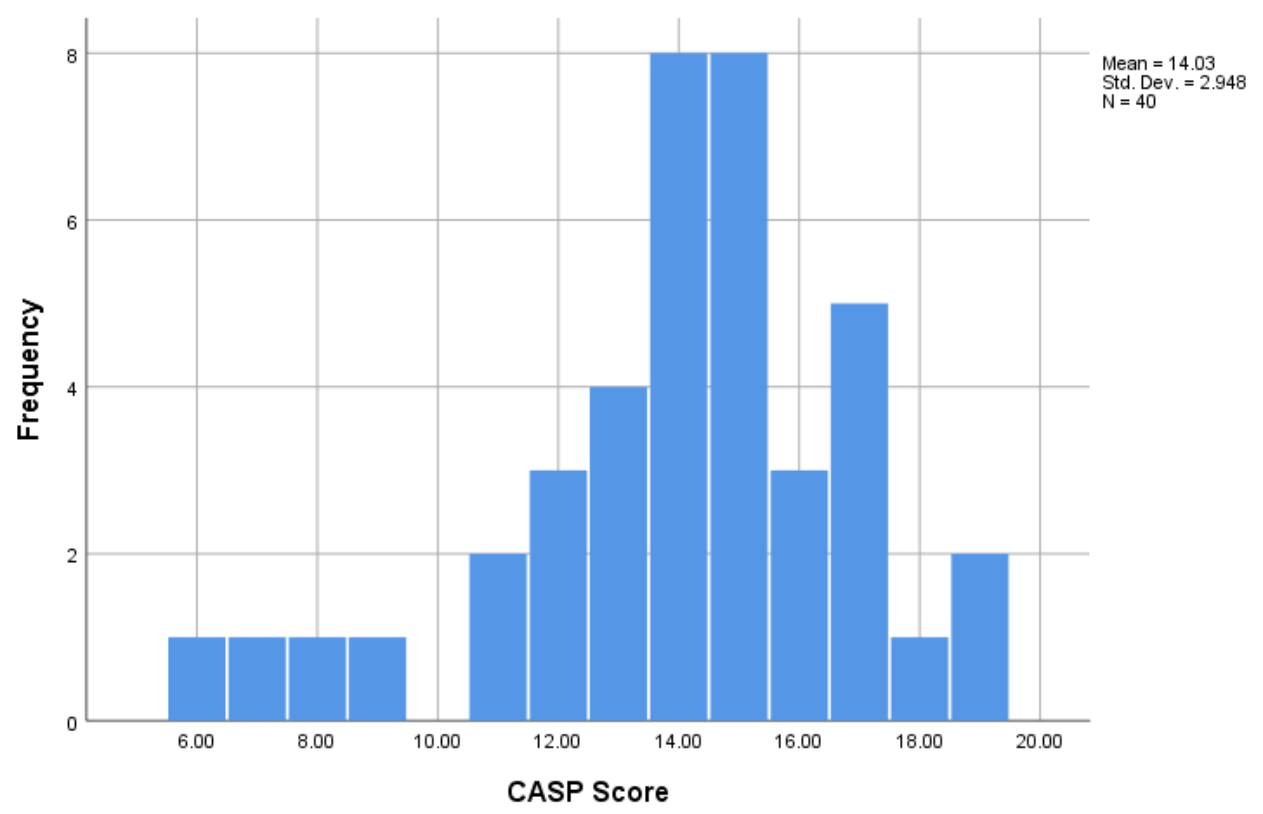

Figure 2: Histogram plot of the CASP scores for all forty articles reviewed

The CASP score evaluating the quality of the articles was checked in order to identify any themes that only appeared in lower quality work. The scores ranged from 6 to 19 out of a possible 20, Figure 2. Out of the 40 articles, 27 had a score of 14 or greater and 4 had a score less than 10 . The majority of the articles had a clear statement about their aims, findings and had taken ethical issues into consideration for the research, Table 4 . The research design (question 3) was only partially appropriate in 21 of the 40 studies, often failing to justify the type of collection method used. Twenty-four of the studies only partially met the recruitment strategy (question 4) with studies not fully stating the recruitment process or inclusion/exclusion criteria used. Data collection (question 5) was only fully met by 14 of the studies; 24 of the studies partially met the criteria with the development of the interview guide or data collection strategy not fully explained. The majority of the articles, $n=30$, failed to consider the relationship between the researcher and the participants 
of the studies (question 6). No themes were found to be limited to weaker articles so the CASP score was not considered further

Table 4: Number of studies that met, partially met and did not meet each question of the Critical Appraisal Skills Program [48]

\section{Criteria}

\# of

studies

totally

met (2)
\# of \# of studies studies partially not met met (1) (0)

\begin{tabular}{lccc}
\hline 1. Was there a clear statement of the aims of the research? & 29 & 11 & 0 \\
\hline 2. Is a qualitative methodology appropriate? & 38 & 2 & 0 \\
\hline 3. Was the research design appropriate to address the aims of the research? & 19 & 21 & 0 \\
\hline 4. Was the recruitment strategy appropriate to the aims of the research? & 13 & 24 & 3 \\
\hline 5. Was the data collected in a way that addressed the research issue? & 14 & 24 & 2 \\
\hline $\begin{array}{l}\text { 6. Has the relationship between researcher and participants been adequately } \\
\text { considered? }\end{array}$ & 1 & 9 & 30 \\
\hline 7. Have ethical issues been taken into consideration? & 28 & 8 & 4 \\
\hline 8. Was the data analysis sufficiently rigorous? & 16 & 18 & 6 \\
\hline 9. Is there a clear statement of findings? & 28 & 12 & 0 \\
\hline 10. How valuable is the research? & 24 & 12 & 4 \\
\hline
\end{tabular}




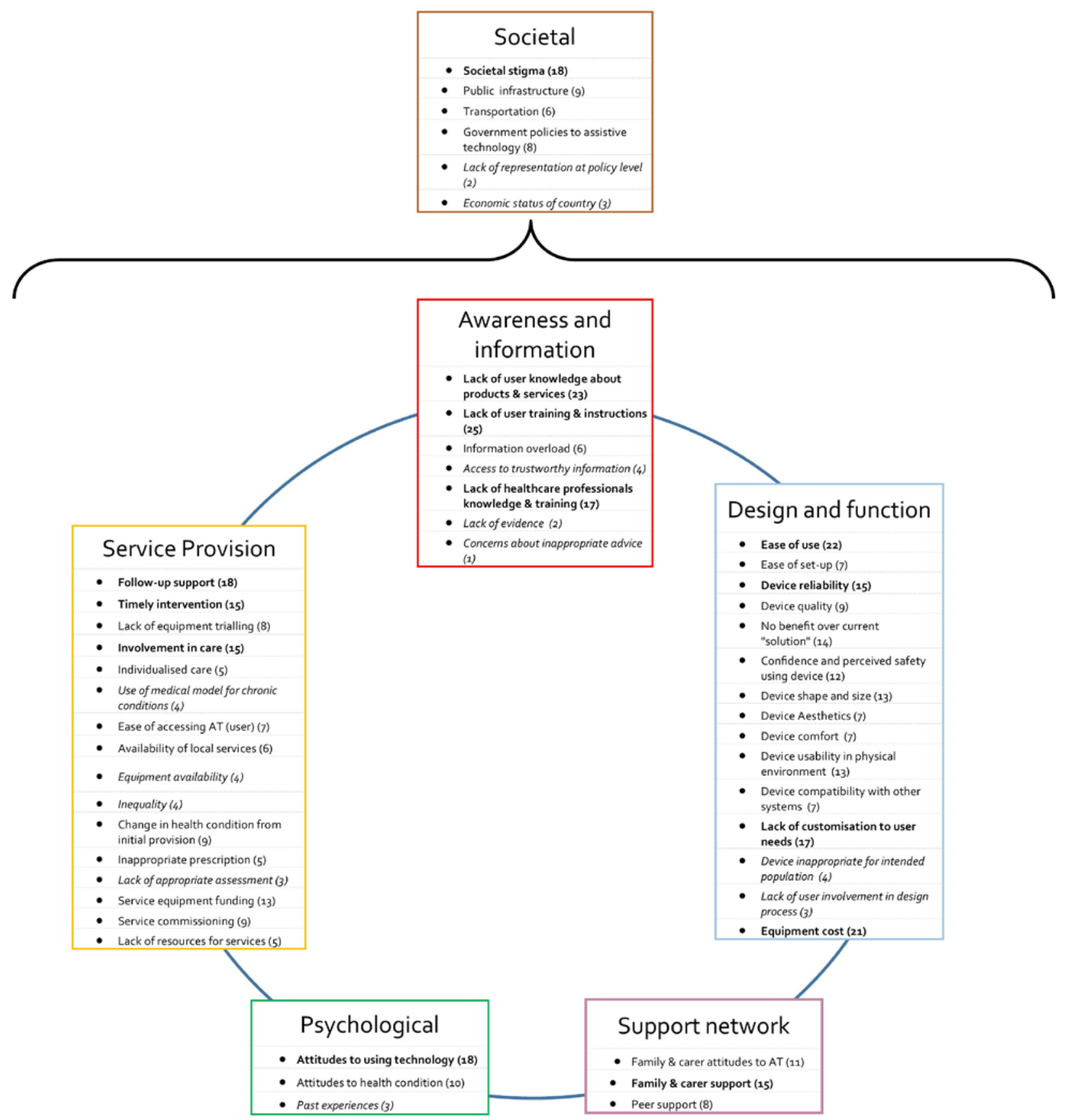

Figure 3: Summary of analytical and descriptive themes. Bold descriptive themes identified 15 times or more, italics descriptive themes identified less than 5 times

\section{Analysis findings}

Six analytical themes describing the barriers to assistive technology were derived from the grouping of the 50 descriptive themes identified in the articles, Figure 3. The six analytical themes related to: the design and function of assistive technology, awareness and information, the service provision of assistive technology, personal psychological barriers, support network and societal barriers. Each analytical theme and subsequent descriptive themes are described in more detail.

\section{Theme 1: Design and function}


This theme groups the descriptive themes identified relating to the design and function of assistive technology. Users remarked that the ease of use of devices was a barrier to the on-going use of assistive technology. Users wanted devices that were simple to use and operate [49,51$53,55,57,58,61-63,67,69,73,74,76,78-80,82,83,85]$. The ease of set-up of their assistive technology for example how difficult or how much of a 'hassle' a device was to set-up would influence the users decision to use assistive technology $[55,58,61,62,73,76,85]$.

Device reliability refers to if the device was able perform consistently its intended function. Poor reliability, such as devices giving false notifications or being inconsistent in performing a function, led to low confidence in the performance of the device and abandonment of the assistive technology $[49-51,55,62,65,66,69,71,73,76,78-80,85]$. The quality of the device was also a barrier that was identified by users. This related to devices breaking easily due to being too fragile or not durable enough for the intended use of the assistive technology $[59,62,65,67,69,72,73,78,87]$.

The perceived benefit over current "solutions" relates to the assistive technology had to be more useful than any previous or current solutions that users were accustomed to using for it to be accepted by the user $[52,53,55,57,66,69,73,74,76,78,81,82,84,85]$. Participants also had concerns regarding their confidence and safety when using the device. This related to users being un-sure how to use the device, having concerns regarding feeling safe or how the assistive technology impacted on their privacy $[51,53,55,58,64,66,67,73,76,78,79,87]$.

Aspects relating to the physical shape, size and weight of a device were also identified by users as a barrier to using their assistive technology. Examples identified included the assistive technology being too big for the user to carry or too heavy to use $[49-51,54,55,60,61,67,70,73,78,80,81]$. The aesthetics of a device were also discussed by some users as a barrier to using their assistive technology. Users were concerned that devices looked too medical and not enough like mainstream technology; this resulted in user's feeling stigmatised and embarrassed to use the devices $[57,73,75,76,78,81,85]$. How comfortable a device was to user and wear was identified as another barrier. Issues with device discomfort included pain which limited the use of the device $[60,61,63,67,68,73,87]$.

Participants described how the design of the device made it unsuitable for use in certain environments. This included due to the outside climate, for example sunlight causing glaring on screens or high temperatures causing overheating, and due to the constraints in a user's home, for example narrow spaces and carpets. Additionally, the devices being unsuitable for the local environment they resided in for example on dirt roads, where there are no paved roads or foot paths available, or being unsuitable for the local language and cultural needs $[49,53,54,59,63,69,70,72,73,77,78,83,85]$. The compatibility of the assistive technology with other systems and device restricted user's usage of the assistive technology. For example, being able to access their phone or control the television through their wheelchair controls or communication devices. $[49,61,62,67,72,73,80]$.

Another barrier with the design of assistive technology related to the lack of customisation to the end user needs. Both users and prescribers described how a universal design or one size fits all approach to assistive technology design was not appropriate to cover the individual needs and circumstances of each user $[49,51,54,55,57,60-63,72,73,78-81,85,87]$. Another sub-theme that restricts usage of assistive technology was if the device was inappropriate for the intended population. Users felt that devices were too difficult or too childish for older adults to use as they were not designed with older users in mind. Additionally if the device function did not adequately 
compensate for the limitation, then it was not appropriate for the population being used on $[49,51,66,80]$. A lack of user and therapist involvement in the design process for assistive technologies was another barrier. End users, carers and therapists believed they could provide useful feedback and suggestions during the development and testing of new assistive technology to improve the design of assistive technology [58,72,81].

The final sub-theme relating to the design and function of assistive technology was the initial equipment cost and on-going maintenance cost for participants and services. Assistive technologies deemed as medical devices were perceived as being too expensive to purchase, especially compared to conventional products and technology $[50,53,56,58-61,64-66,71-74,77-81,84,87]$.

\section{Theme 2: Awareness and information}

This theme groups the descriptive themes related to the awareness of and information about assistive technology. A lack of training and instructions provided to the end user, family and carers regarding the safe and appropriate use of the assistive technology was a barrier to people using their assistive technology. This included a lack of written information or lack of time spent familiarising the user with the device $[37,51,53-55,57,61-68,70,73,74,76-78,82-85,87]$. A barrier to accessing the assistive technology for users, family members and carers was a lack of knowledge about the products and services available to them. Users were unsure about who was responsible for providing the equipment, how to access the services and what equipment was available $[37,49,53-$ $56,58,60-66,69,70,73,74,77,78,81,83,86,87]$.

Information overload describes users and carers who were given too much information about products and services available. The overload of information meant people struggled to manage and understand all of the information provided and as a result individual's felt overwhelmed so they retained very little information $[55,64,69,76,82,85]$. Accessing trustworthy information about products and service available was a barrier to acquiring assistive technology as individuals wanted un-biased opinions from trusted sources about whether the assistive technology was going to be useful for them. Individuals had concerns relating to the quality and relevance of information from the internet, national press and sales representatives $[37,58,72,86]$.

Another barrier was the lack of knowledge and training of healthcare professionals about assistive technology that was available. End users felt that healthcare professionals lacked sufficient training on the operation of the devices, up to date knowledge about both products available and how to access them $[37,49,53,56,58,59,62,64-66,69,71,72,76,78,85,87]$. An additional barrier to the provision of assistive technology was the lack of evidence available to healthcare professionals and commissioners regarding the effectiveness of assistive technology. Information regarding relevant and accessible research and clinical testing of assistive technology was limited $[58,61]$. The final theme relating to information and awareness was healthcare professional's concerns about giving inappropriate advice about assistive technology that could influence the decision to purchase a product privately. Therapists were concerned about endorsing products that had limited evidence [58].

\section{Theme 3: Service provision}

This theme groups all the descriptive themes related to the provision of assistive technology to the end user by the service and equipment provider. Fifteen descriptive themes were categorised under this theme. A common barrier to the use of assistive technology was the lack of follow-up support 
by service providers to the end users. Users described how they received no specific follow-up after the device was issued to check on the equipment to support for its ongoing use. This included a lack of maintenance and repair support for when devices break

$[37,49,50,54,55,57,58,60,64,66,69,73,76,82-85,87]$. The timing of the intervention or when assistive technology was provided to the user was an important factor in its uptake. Examples included equipment being provided too late after the user's condition had deteriorated past the point it was useful. Long wait times for appointments or delivery of the equipment were regularly mentioned in relation to this theme $[49,53,54,56,62,64,66,68,69,74-76,78,82,85]$. A lack of equipment trialling to test if the equipment will work in a user's real-life context prior to equipment provision was another barrier. Many user's wanted but did not get a period of time to try out equipment in different environments before choosing if the equipment was appropriate for them $[57,58,61,63,64,68,84,85]$.

A lack of involvement in care decisions and assistive technology choice was another barrier to the use of assistive technology. Users wanted individual choice in the equipment being provided to them and a lack of involvement resulted in frustration and disagreement with the prescriber $[49,51,52,54,55,57,66,68,70,72,73,75,76,82,84]$. Failure to account for individualised care needs showed users wanted to be treated on an individual basis and not feel like they were being categorised (due to their health condition). Use of generic evidence to access benefits of equipment, the use of scoring system for assessments and being insensitive to personal attitudes, habits and environment all made the process seem impersonal to the user $[57,58,66,82,83]$. The use of the medical model for treating chronic conditions by healthcare services limited the availability and provision of assistive technology. A focus on short term rehabilitation goals, for example, discharge from hospital, resulted in a lack of consideration to providing assistive technology that could provide long-term benefit $[37,58,64,66]$.

The ease of accessing assistive technology due to the paperwork and number of steps required was a barrier to acquiring the assistive technology. Participants expressed it took a lot of time and energy to go through the application processes $[49,56,60,65,72,75,78]$. The availability of local services was a barrier to accessing the services and assistive technology required. Long travel times to and from services meant participants would give up accessing services $[60,61,64,77,83,87]$. Another barrier was the availability of equipment services could provide to the end user. Services had difficulties sourcing and obtaining appropriate products within the country $[54,59,71,83]$. Some users were unable to access assistive technology from services due to inequality in who equipment was provided to, with their disability seen as not severe enough. Strict eligibility criteria limited the availability of potentially useful equipment to certain groups $[54,61,83,87]$.

Changes in health condition from the initial provision of the assistive technology meant that the assistive technology was no longer appropriate for the user to use. Changes could be due to an improvement or deterioration in cognitive or physical abilities $[53,55,62,67,74,76,82,84]$. An inappropriate prescription was a barrier when the device provided to the user was unsuitable to meet their needs. Examples included incorrect sizing, the user never needing the device or the user was cognitively not being able to operate the device $[73,81,83,84,87]$. An appropriate assessment was required to ensure all the requirements for the individual were captured prior to device provision. Assessments needed to be undertaken in an appropriate environment, potentially 
multiple locations, that was suitable for the individual to prevent future issues with the use of the assistive technology $[54,76,85]$.

Limitations in equipment funding for services to purchase and provide assistive technology was another barrier. Funding restraints on services limit the quantity and range of equipment available through public services and meant equipment provision often had to be prioritised to users with greatest need $[53,54,58,59,61,64,74,75,77,78,83,85,87]$. The commissioning of services restricts the provision of certain types of assistive technology, introducing in-equality in the provision of services. Funding decisions for assistive technology based on generic evidence, irregularities between geographical locations in a country and low priority status of some health conditions result in bias and inequality in service provision $[37,49,54,58,64,66,78,81,85]$. A lack of resources for healthcare and equipment services was another barrier to assistive technology. Time pressures and resource limitations restricted the ability of services to effectively provide, train and follow-up with clients $[37,58,64,83,85]$.

\section{Theme 4: Psychological}

The theme psychological barrier group's descriptive themes relating to the user's personal opinions and perceptions that act as a barrier to accessing and using assistive technology. A negative attitude towards using technology and assistive technology by the end user was a barrier to using assistive technology. When the end user was against the idea of using technology due to it being perceived as annoying, awkward or not appropriate for them, the personal attitude of the individual influenced the use of the assistive technology $[52,53,55,58,61,66-68,70,74,77-79,81-83,85,87]$. The end user's attitudes towards their health condition relates to the end user need to accept their current health condition and the need for help before they are willing to use assistive technology. The acceptance of needing help could be distressing and depressing for the users; this barrier needs to be overcome before assistive technology is accepted [52,55,61,66-68,70,74,82,87]. Past negative experiences with assistive technology influenced the acceptance of the current assistive technology by the user. Examples included if a device did not work in the past, caused pain or the user had past disappointments with a service $[71,83,87]$.

\section{Theme 5: Support network}

The theme support network reflects the influence that the close support network to the individual, for example family, carers and friends, can have on acquiring and using assistive technology. The negative attitudes of family and carers towards assistive technology could influence the use or nonuse of assistive technology by the user. A perception by family and carers that equipment is not wanted or required influences the attitude of the user and impacts on the use of the equipment. $[49,52-54,57,59,66,82,83,85,86]$.

Another theme relating to the support network was the consequence of a lack of engagement and inclusion of family and carer's to support the user during the prescription, issuing and training of the assistive technology. If the family and carers did not "buy into the idea" of the assistive technology, then users lacked the required support to use and become familiar with the assistive technology for more independent use $[37,49,53,54,57,64,66,69,75,76,80,82-85]$. Users also wanted to learn about how to use assistive technology from those with similar conditions who knew what it was like to use the assistive technology through a peer support environment instead of being given information by 
therapists and equipment suppliers. Currently users felt there was a lack of opportunities to access peer support $[37,49,51,52,54,64,77,83]$.

\section{Theme 6: Societal barriers}

This theme groups descriptive themes relating to wider societal issues that are a barrier to the access and use of assistive technology. Users often felt stigmatised by society when using assistive technology. The negative attitudes of others towards them made individuals feel vulnerable, selfconscious and embarrassed using their assistive technology in public places $[49,50,52,54,55,59,63,65,67,68,70,73,74,78,81,84,85,87]$.

The design and construction of public infrastructure, for example buildings, roads and paths reduced the accessibility of the physical environment to assistive technology users, becoming a barrier to its use. Lack of access ramps, narrow corridors and aisles, high counters and a lack of appropriate parking spaces all limited assistive technology use $[50,59,63,68,70,73,77,78,87]$. Limited and poorly designed public transportation was also a barrier to the use of assistive technology in the community $[50,59,63,70,83,87]$.

The government policies towards assistive technology priorities, commissioning and provision of equipment produced barriers accessing assistive technology. For example, policy driven agendas towards increasing diagnosis rates of dementia, national assistive technology lists and a lack of recognition for assistive technology in a government's agenda impacted on the provision and use of assistive technology $[37,49,54,59,74,77,83,87]$. Assistive technology user's were concerned that they had a lack of representation at policy level, which impacted on the national agenda and government policies towards assistive technology $[54,60,77]$. A final sub-theme relating to societal barriers was the economic-status of the country. Issues such as widespread poverty limited the availability of funding for assistive technology and people lacked funds to purchase assistive technology themselves $[77,83]$.

\section{Discussion}

Assistive technology could reduce the burden chronic conditions put on health services and increase the independence, participation and social engagement of individuals with chronic conditions [22,24-27]. However, this potential unrealised with assistive technology abandonment rates between 20-70\% [28-32]. This meta-synthesis identified six overarching barriers to obtaining and using assistive technology: design and function of assistive technology, awareness and information, the service provision of assistive technology, personal psychological barriers, support network and societal barriers, Figure 3 . The barriers are common across health morbidities, Table 1 , and multiple themes are present in each article. Therefore, the barriers should be considered in combination as a summary of researchers understanding of the issues that inhibit assistive technology deployment. To improve the usage of assistive technology, a single strategy targeting one of these aspects - for example improving the design and function of assistive technology - would fail if related interlinked barriers were not also addressed. The themes interlinking and relationship to the wider biopsychosocial models of disability and wellbeing form the basis of this discussion.

\section{Design of assistive technology}

Berkun (2004) describes the three elements of 'good' design [88]: 
- Performance: how well it does the job it is fit for

- Engineering: how safe, well-engineered and reliable it is

- The aesthetics of experience: how the whole interaction with the product/service feels and is experienced

Barriers relating to all three of these aspects such as ease of use, reliability, and comfort were identified in the analysis and are consequences of 'bad' design. The idea of 'good' or 'bad' design is subjective and what a designer perceives as 'good' due to meeting design specifications, may not meet the needs of users. This problem is discussed throughout design literature and stems from a range of misunderstandings but in healthcare a significant reason for this difference is a gap in perspective between designer and people living with the impairments they are designing support for [89]. Increased user involvement in the design of assistive technology would improve this [30,33-35].

Our analysis showed assistive technology lacked customisability needed to meet individuals' needs. The success of technology rests on integration into the users' local, habitual routines [90,91]. However, their experiences and assisted living needs are diverse and unique [92] due to individual, community and the wider-environmental contexts they resides within $[7,14]$. Therefore, assistive technology does not lend itself to standardised solutions or 'one size fits all' approaches. Pols and Willems (2011) argue that integrating technology depends on individuals tinkering with it to make it meet their needs [93]. Lopez (2015) suggests that technology uptake is dependent on mundane yet complex socially situated and embodied activities that determine the individual's relationship with technology [94]. This leads us to believe that a core feature of assistive technology is that is must be 'adaptable' or 'modifiable' to fit into everyone's circumstances.

Greenhalgh et al. 2013 use the phrase 'Bricolage'[95] describing how individuals, family members and informal carers (the bricoleurs), adapt everyday technology to meet the user's needs. Bricolage combines new and second hand materials to produce one-off devices that solve one-off problems $[96,97]$. The adaption of everyday technology to meet an individual's needs and circumstances is found in studies relating to telehealth, telecare, and dementia care [91,95]. Gibson et al. (2019) found bricolage is commonly used informally by carers and, to a lesser extent, people with dementia to overcome everyday issues in place of formally provided assistive technology [91].

The success of bricolage hinges on: using everyday items that are already part of an individual's routine; understanding user's needs through the close relationship between user and bricoleur; adapting devices when needs change due to changes in the user's health or circumstance; and saving money with low-cost everyday technologies overcoming the barrier of equipment cost. However, bricolage is dependent on the creative engagement and problem solving by the bricoleur, so it is not accessible to all people. Given the evidence from our analysis shows many of the barriers to assistive technology are common across different health conditions, it would be interesting to investigate how bricolage techniques are used across other health populations alongside formal assistive technology provision.

\section{Social context}

Based on our review, an individuals' societal context presents barriers to assistive technology use in line with the ICF and GENIAL frameworks that emphasise the impact of communities and wider environmental context on disability and wellbeing. Government policies on assistive technology, link to the social context of ICF and GENIAL and ultimately influence barriers including accessible 
infrastructure and transportation, commissioning and funding of assistive technology services and equipment cost.

Overcoming infrastructure and transportation barriers requires work to address them in the urban environment's planning and building and assistive technology's design. National and local governments must ensure environments are open to assistive technology use to promote accessibility and companies must ensure device designs are usable in these environments.

The commissioning and funding of services needs to reflect a change in approach to chronic condition management. Government policies are more focused on diagnosis [37] and short-term rehabilitation treatment goals, based on the traditional acute medical model, rather than focusing on services to promote long-term self-management for individuals with chronic conditions. The use of bricolage, alongside more formal assistive technology provision, could overlap with selfmanagement principles by the user or their family. However, more funding would be needed to support and implement any long-term strategies for managing chronic conditions. This approach is challenging as it must be balanced against short term emergency medicine and care needs.

The barriers related to societal issues must also be placed in the wider economic context of the country. For example, several articles discussing less economically developed countries such as Nigeria and Uganda, highlight that assistive technology is a low priority due to more wide-spread social and economic issues such as poverty, famine and lack of infrastructure within the country $[77,83]$.

Societal stigma as identified in previous work $[34,98]$ arises due to a lack of awareness, lack of education and misperception [99]. Assistive technology stigma is also partly due to the aesthetics of the assistive technology [98]: "Why does it all have to be beige-brown and look like it's out of the infectious disease ward? You know, we already stick out enough, we don't need anything else added." [85]. The behaviour and attitudes of the wider public influence the attitudes of the individual and their family [100]. This has implications for social participation, mental health, and physical health [98]. This stigma causes some people to avoid using their assistive technology when out in public and raises the question of how we can make assistive technology look less "medical" and more "mainstream". Changing the wider public's views about assistive technology, and more widely views regarding disability, is needed to promote the use of assistive technology for the individual.

Bricolage's adaption and use of more mainstream technology, improvements to the design of assistive technology to make devices look less medical, or information and educations strategies to improve the wider public's awareness of assistive technology could all help to address societal stigma. We also see again that involving end users in the design process could add considerable value in reducing the 'stigma' barrier.

\section{Individual context}

The device itself is important but so is understanding the psychological processes that may facilitate its usage. Psychological barriers identified in our review related to both the individuals' acceptance of needing help and how they adjust to a change in routine. The ICF and GENIAL frameworks characterise the factors influencing the experience of disability by an individual including age, gender, social background, education and professional background, character and behaviour 
patterns [14]. In the context of assistive technology, these factors could influence the psychological barriers for each individual. Theories of behaviour change might help to overcome the psychological barriers to assistive technology to reduce the abandonment rate. Five factors have been identified as key to maintaining behaviour change: motivation to want to change; self-regulation through goalsetting; developing new favourable habits; resource, both psychological and physical, to overcome the barriers to change; and influences of both the social and environmental context [101].

Overcoming these barriers may require psychological support as well as the right information and right device.

Failure to improve over current solutions, Figure 3, showed individual context must be considered when deploying assistive technology. Assistive technology should be sought out by the user or their support network as opposed to being pushed onto them assuming it is an improvement over their current coping mechanism. Deployment should be based on a user's wishes and, where possible, enhance rather than replace their current management strategies. This requires collaboration between clinicians, users and support networks to understand what matters to the client [92]. This would also necessitate involving the client in their cares decision-making process moving away from the acute medical model's 'passive recipients' of care.

Social influences on behaviour change are also linked to societal stigma. Support network's attitudes to using assistive technology can be barrier as is the usually unmet desire for peer support from others who have used the equipment when learning about it - in the GENIAL model community can drive change [7]. Greenhalgh et al. established that personal interactions with social networks can make or break the telehealth and telecare [92]. We build on this by showing the importance of the social network for assistive technology solutions. We are led to ask how community can be better integrated into assistive technology. Creating a community for providing assistive technology would encourage peer support and knowledge sharing as well as having secondary benefits like social engagement and inclusion that influence positive behaviour change and wellbeing.

\section{Healthcare context}

The service provision of assistive technology needs to include more support to users following provision, more timely interventions and more involvement of users in their care to make it suitable for their needs, Figure 3. Personal context is not static, rather context and use are dynamic and coconstitutive [102]. Follow-up support can identify if a change in health or personal or environmental factors mean a device is no longer appropriate. Wherton et al. (2015) argue that the installation of assistive technology must cease to be a one-off technical event and instead be an ongoing process where personal and social supports are built through continued relationships and social networks [103]. This analysis shows this is applicable beyond their context of telehealth and telecare provision and should be explored in relation to all assistive technology provision. This requires a change in focus from user's being viewed as passive consumers to instead integrating them into their care, building strong inter-personal relationships and enabling technology to be readily adapted to a change in context.

Restrictions on service provision are partly due to lack of equipment funding, service commissioning and resources. As previously identified, this is partly driven by government policies and funding for assistive technology and, with more funding, services would be able to overcome many of the barriers as they could, for example, provide more follow up support, more timely intervention and let the user trial assistive technology. However, not all barriers in service provision are related to 
funding, for example, the need for individualised care. Substantial increases in funding and resources are unlikely in the short term so services need to focus on developing more effective methods to provide and support individuals. Transdiagnostic services could achieve this by reducing duplication in staff and resources, providing more cost-effective strategies as barriers to assistive technology are similar across chronic conditions.

Co-production could involve users and produce individualised care. Co-production is a personcentred approach where service-users are placed into an equal partnership with healthcare professionals for managing their health and wellbeing [104]. The approach differs from traditional models of healthcare where the clinician are seen as the "expert" and the user a passive recipient of care [6]. Co-production instead identifies the user as the expert in their own condition and lived experience with unique knowledge of how they manage their own health. This changes the role of the clinician from a prescriber using pre-defined criteria to give a "menu" of assistive technology, to adviser. The clinician uses their experience and knowledge to work with the client to implement strategies, techniques, and, where appropriate, technology. This closely links to the idea of bricolage [95]. In this respect the client can learn from the clinician, but equally importantly teaches the clinician what works for them based on their lived experience improving the clinician's knowledge which can in turn be shared with other clients. Integrating co-production approaches would require a culture shift of how services are designed to manage chronic conditions.

\section{Information and awareness}

Users and therapists lacked reliable information and awareness about assistive technology $[22,38,44]$. Information and education improve awareness and inform users and healthcare professionals about the products and services available, enabling users to make a choice to engage. They also ensure users can operate devices and inform and improve awareness in wider society of assistive technology which discourages stigma. Users lacked information about how to access and use assistive technology, and lacked information about the benefits of using assistive technology that is important in the context of behaviour change for motivating adoption [101]. Healthcare services should provide information that is unbiased and trustworthy however, there is a fine balance between insufficient information and overloading with too much information. Information also needs to be available to users, family, carers and healthcare professionals that is disabledaccessible and trustworthy.

Healthcare professionals need to maintain up to date knowledge and training if they are to appropriately respond to user's needs. This is linked to service provision and currently a lack of resources may influence healthcare professional's capacity to keep up to date with the range of assistive technology available. Online databases could help collate information about assistive technology and include everyday technologies and strategies people use. This could enable user's and therapists to share information, strategies and reviews about what works for them. 'Dementia Circle' (www.dementiacircle.org) evaluates and shares products and digital solutions to help people living with dementia. To ensure such a resource is accessible and useful it must be developed with input from the stakeholders: users, family, carers and healthcare professionals.

\section{The role of evidence in assistive technology}

Although a lack of evidence was only directly identified in two articles, it can have a causal impact on multiple other barriers including government policy, service commission and equipment funding. 
The lack of evidence should be examined in the context of the current dominant model: evidencebased medicine (also referred to as evidence-based healthcare) [105]. Evidence based medicine aimed to ensure that clinical practice became more scientific and empirically grounded. Evidence from large randomised control trials (RCTS) and observational studies are used to produce clinical guidelines to determine the commissioning and funding of treatments. The approach relies on the assumption that "best evidence" would be objectively verifiable and readily updated with new research [106]. However, it is now facing a crisis as evidence quality has been misappropriated by vested interests, the volume of evidence and clinical guidelines are unmanageable, statistically significant benefits may be marginal i.e. not clinically meaningful, inflexible guidelines produce care that is management driven and not patient centred, and guidelines map poorly to complex multimorbidities [107-109].

The use of evidence-based medicine shares barriers with assistive technology. First, a limited number of randomised control trials have been successfully reported on with assistive technology, especially compared to other healthcare interventions like drug trials. Second, traditional evidencebased medicine is based on controlled laboratory testing dealing with objective, carefully-controlled measures [109]. However, as evidenced in this review and GENIAL and ICF frameworks show, the use of assistive technology is personal, complex, and has a host of confounding factors associated with the individual, community and environment $[7,14]$. This complexity may explain why RCTs are rare. It also indicates that generic evidence produced about an assistive technology is not as generalisable as drug trail results are. For example, Demain et al. (2013) state "(stroke patients) were less interested in generic findings, arguing that every person with stroke is different and that evidence of benefit should be sought on a case-by-case basis" [58].

The need for evidence-based medicine and high quality RCTs is not disputed, instead we question the applicability of this type of evidence for assistive technology provision. Real evidence based medicine addresses some of the concerns with evidence based medicine [109] as it emphasises ensuring healthcare is individualised to the patient, that care is based on clinical judgement and not wholly prescriptive rules and the importance of a strong patient, clinician relationships. It calls for patient's experiences to be included through qualitative techniques that are complementary to the application of research evidence [110].

There is evidence that experiential knowing, through having lived with a condition, is important in self-management $[95,111,112]$. This evidence base has more relevance to an individualised approach to assistive technology provision. Thus, it is important that policy makers and service commissioners recognise that assistive technology provision is centred on an individual's unique needs and social context. Such subjectivity cannot be reproduced in randomised control trials and therefore the evidence required for assistive technology funding should reflect a more individualised, patient focused approach. How to practically achieve this approach is challenging and complex, requiring a culture shift at all levels of healthcare provision: clinicians, management and commissioners.

\section{Comparison with other literature}

The ARCHIE framework defines the quality principles for designing, installing and supporting telehealth and telecare products and services [92]. ARCHIE was developed from interviews, ethnographic, and workshop activities focused on telehealth and telecare finding services should: anchor in a shared understanding of what matters to the users, take realistic approaches to illness 
progression, continuously co-create solutions with users and carers, encourage inter-personal relationships to support use, integrate methods of sharing knowledge between individuals and services, and be rigorously evaluated using appropriate research methods. The reasoning behind the development of this framework follows many of the barriers identified in this review: lack of customisation and user involvement, poor information sharing and knowledge, and lack of ongoing social interaction and support. Therefore, based on the results of this analysis, a similar framework could be suitable for the provision of all assistive technology.

Instead of traditional assistive technology provision, the role of healthcare services could instead be implementing approaches that support the client's discovery of techniques and strategies that help them manage themselves. This approach would focus on both physical and mental health and operate as a multi-disciplinary, trans-diagnostic service supporting self-management, health and wellbeing. The use of technology, for example bricolage solutions or assistive technology, can form part of this, but should not be considered the overall goal. This is not routinely done and achieving this requires a re-think of how services operate [92]. Aspects of the Maker movement, community based spaces where individuals can design and fabricate their own technology [113], could provide an approach that more formally encourages the development of bricolage solutions in healthcare services. A maker space is also a community space and could encourage collaboration, social engagement and support between the user, family, peers and healthcare professionals. This can enable the sharing of knowledge, skills, and adaptions of devices already being used by people to overcome everyday issues. This approach is very different to current assistive technology provision based on 'menus' of products that can be supplied and strict eligibility criteria [92] and encourages collaboration, creative thinking and problem solving. Exploring how aspects of the Maker approach could be incorporated into formal healthcare services to encourage strategies of, for example, selfmanagement using bricolage would be an intriguing avenue for future research.

\section{Limitations}

One limitation of a meta-synthesis is the information analysed is dependent on the results and quality of the articles included. The articles reviewed were characterised by varied research questions and methodologies deployed in different environments and contexts. The meta-synthesis process may thus mask certain shortcomings of articles, especially those with low methodological quality. Although there is no standardised method for assessing the quality of research currently, the CASP tool has been widely used for assessment of article quality and enables comparison between studies in different contexts.

Another limitation with meta-syntheses is that the context of each individual article can be lost during the synthesis and the context of one study may not carry over to other studies. However, we examine and report on country, population and type of assistive technology for each article, enabling the reader to establish their context for themselves.

A final limitation of meta-syntheses is that thematic analysis of data is subjective, based on the authors own background and understanding of the topic. This concern was ameliorated through regular discussion with the wider research team at different stages of the research process, including discussion of theme synthesis and convergent interpretation of the results. This served to reduce the bias relating to individual subjective interpretation of the data.

\section{Implications for future research and practical applications}


This meta-synthesis aimed to identify the common barriers to assistive technology in the context of establishing more effective healthcare services to improve health and wellbeing in individuals with chronic conditions. The findings demonstrate the issue is multifaceted, relating to a wide range of aspects from the design of assistive technology devices, to attitudes of the individual, provision of healthcare services and wider societal barriers. The evidence suggests individuals want more customised solutions and greater involvement in their care to better support their bespoke needs. While the initial focus was on assistive technology, we argue that assistive technology must be implemented alongside current solutions and techniques already used by the individual and should encourage the adaption of everyday technologies that are readily available and customisable to meet individual needs. Exploring how individuals adapt strategies and everyday household technologies to meet their needs warrants further research. We have identified how aspects of the Maker movement could be used to overcome the barriers to assistive technology and more widely be used to encourage positive health behaviours for health and wellbeing. The extent to which this is practically feasible for creating more effective models of healthcare for chronic conditions and its impact on health and wellbeing also warrants future research efforts.

Another important consideration is the access to and dissemination of information to both user's and healthcare professionals. Strategies to ensure trustworthy, accessible and relatable information are important to ensure people are aware of the service and technical solutions available to them, either household technologies or more formal assistive technology. Future research should look at the use of online tools to better disseminate information about solutions people use. This should be done in collaboration with key stakeholders. Future research should look at the issues presented by social stigma and how to change the perceptions of disability and assistive technology by the wider public

The approaches put forward here require a cultural shift from traditional assistive technology provision and is no doubt a complex and challenging solution. However, the approaches are based on the results of our systematic analysis combined with established models of health and wellbeing, a focus on individualised care, self-management and pre-existing frameworks for assistive technology provision. It requires buy in from all levels of society: government, industry, commissioners, management, clinicians and the users themselves. Several key challenges to achieving this are summarised below:

- A change in emphasis from the "expert" clinician to more patient specific solutions, where individuals are involved in their care and decisions are based on the individuals lived experience and their personal and social context, they reside in.

- How to encourage creativity to solve problems and enable exploration of both everyday technology and assistive technology to suit the user needs, rather than relying on restrictive, prescription-based lists of pre-defined assistive technology

- The way technology provision is evaluated. A change in focus from purely measurable objective outcomes to a wider context of changes to health and wellbeing for the individual.

\section{Acknowledgements}


We acknowledge the support of Swansea University and the National Health Service in recognizing and promoting our work through various awards including the University Research and Innovation Award for Outstanding Impact on Health and wellbeing (2018) and the Swansea Bay University Health Board Chairman's VIP Award for Commitment to Research and Learning (2018). We further acknowledge grant funding from Health and Care Research Wales through the Research for Public Patient Benefit Scheme (RfPPB-18-1502), which is supporting our efforts to lay the foundations for a more sustainable future healthcare sector.

\section{Declaration of interest statement}

The authors report no conflicts of interest 


\section{References}

1. Kyu HH, Abate D, Abate $\mathrm{KH}$, et al. Global, regional, and national disability-adjusted life-years (DALYs) for 359 diseases and injuries and healthy life expectancy (HALE) for 195 countries and territories, 1990-2017: a systematic analysis for the Global Burden of Disease Study 2017. The Lancet. 2018;392(10159):1859-1922.

2. World Health Organisation and World Bank. World Report on disability. Geneva, Switzerland2011.

3. Foreman KJ, Marquez N, Dolgert A, et al. Forecasting life expectancy, years of life lost, and all-cause and cause-specific mortality for 250 causes of death: reference and alternative scenarios for 2016-40 for 195 countries and territories. The Lancet. 2018;392(10159):20522090.

4. Dieleman JL, Sadat N, Chang AY, et al. Trends in future health financing and coverage: future health spending and universal health coverage in 188 countries, 2016-40. The Lancet. 2018;391(10132):1783-1798.

5. Department of Health. Long Term Conditions Compendium of Information: Third Edition. In: Health Do, editor. 2012.

6. Keller VF, Gregory Carroll J. A new model for physician-patient communication. Patient Education and Counseling. 1994 1994/06/01/;23(2):131-140.

7. Mead J, Fisher Z, Lowri W, et al. Rethinking wellbeing: Toward a more ethical science of wellbeing that considers current and future generations. Authorea. 2019.

8. Anderson RM. Patient Empowerment and the Traditional Medical Model: A case of irreconcilable differences? Diabetes Care. 1995;18(3):412-415.

9. Grumbach K. Chronic Illness, Comorbidities, and the Need for Medical Generalism. The Annals of Family Medicine. 2003;1(1):4-7.

10. Ekman I, Swedberg K, Taft C, et al. Person-Centered Care - Ready for Prime Time. European Journal of Cardiovascular Nursing. 2011;10(4):248-251.

11. Barlow J, Wright C, Sheasby J, et al. Self-management approaches for people with chronic conditions: a review. Patient Education and Counseling. 2002;48(2):177-187.

12. Jordan JE, Briggs AM, Brand CA, et al. Enhancing patient engagement in chronic disease selfmanagement support initiatives in Australia: the need for an integrated approach. Medical Journal of Australia. 2008;189(S10).

13. Dineen-Griffin S, Garcia-Cardenas V, Williams K, et al. Helping patients help themselves: A systematic review of self-management support strategies in primary health care practice. PLOS ONE. 2019;14(8):e0220116.

14. World Health Organisation. International classification of functioning, disability and health (ICF). Geneva: World Health Organisaiton; 2001.

15. Kemp A, Arias JA, Fisher Z. Social Ties, Health and Wellbeing: A Literature Review and Model. In: Ibáñez A., Sedeño L., A. G, editors. Neuroscience and Social Science: The Missing Link: Springer; 2017.

16. Alford VM, Ewen S, Webb GR, et al. The use of the International Classification of Functioning, Disability and Health to understand the health and functioning experiences of people with chronic conditions from the person perspective: a systematic review. Disability and Rehabilitation. 2015 2015/04/10;37(8):655-666.

17. Khasnabis C, Mirza Z, Maclachlan M. Opening the GATE to inclusion for people with disabilities. The Lancet. 2015;386(10010):2229-2230.

18. McNicholl A, Casey H, Desmond D, et al. The impact of assistive technology use for students with disabilities in higher education: a systematic review. Disabil Rehabil Assist Technol. 2019 Jul 23:1-14.

19. Abrilahij A, Boll T. A Qualitative Metasynthesis of Reasons for the Use or Nonuse of Assistive Technologies in the Aging Population. GeroPsych. 2019;32(2):79-92. 
20. Mechling LC. Assistive Technology as a Self-Management Tool for Prompting Students with Intellectual Disabilities to Initiate and Complete Daily Tasks: A Literature Review. Education and Training in Developmental Disabilities. 2007;42(3):252-269.

21. Whitehead L, Seaton P. The Effectiveness of Self-Management Mobile Phone and Tablet Apps in Long-term Condition Management: A Systematic Review. Journal of Medical Internet Research. 2016;18(5):e97.

22. van Ommeren AL, Smulders LC, Prange-Lasonder GB, et al. Assistive Technology for the Upper Extremities After Stroke: Systematic Review of Users' Needs. JMIR Rehabil Assist Technol. 2018 Nov 29;5(2):e10510.

23. O'Neill B, Gillespie A. Assistive Technology for Cognition: A handbook for clinicians and developers. Taylor \& Francis; 2014.

24. Mitzner TL, Boron JB, Fausset CB, et al. Older Adults Talk Technology: Technology Usage and Attitudes. Comput Human Behav. 2010 Nov 1;26(6):1710-1721.

25. Madara Marasinghe K. Assistive technologies in reducing caregiver burden among informal caregivers of older adults: a systematic review. Disabil Rehabil Assist Technol. 2016;11(5):353-60.

26. Lansley P. Can adapting the homes of older people and providing assistive technology pay its way? Age and Ageing. 2004;33(6):571-576.

27. World Health Organisation. Assistive Technology: World Health Organisation; 2018 [cited 201903 November]. Available from: https://www.who.int/news-room/factsheets/detail/assistive-technology

28. Scherer MJ. From people-centered to person-centered services, and back again. Disabil Rehabil Assist Technol. 2014 Jan;9(1):1-2.

29. Phillips B, Zhao H. Predictors of Assistive Technology Abandonment. Assistive Technology. 1993 1993/06/30;5(1):36-45.

30. Martin JK, Martin LG, Stumbo NJ, et al. The impact of consumer involvement on satisfaction with and use of assistive technology. Disabil Rehabil Assist Technol. 2011;6(3):225-42.

31. Sugawara AT, Ramos VD, Alfieri FM, et al. Abandonment of assistive products: assessing abandonment levels and factors that impact on it. Disabil Rehabil Assist Technol. 2018 Oct;13(7):716-723.

32. Scherer M. Living in the State of Stuck: How Assistive Technology Impacts the Lives of People with Disabilities. 2005.

33. Robinson L, Gibson $G$, Kingston A, et al. Assistive technologies in caring for the oldest old: a review of current practice and future directions. Aging Health. 2013;9(4):365-375.

34. Orejuela-Zapata JF, Rodriguez S, Ramirez GL. Self-Help Devices for Quadriplegic Population: A Systematic Literature Review. IEEE Trans Neural Syst Rehabil Eng. 2019 Apr;27(4):692-701.

35. Alqahtani S, Joseph J, Dicianno B, et al. Stakeholder perspectives on research and development priorities for mobility assistive-technology: a literature review. Disabil Rehabil Assist Technol. 2019 Sep 19:1-15.

36. Abdi S, Spann A, Borilovic J, et al. Understanding the care and support needs of older people: a scoping review and categorisation using the WHO international classification of functioning, disability and health framework (ICF). BMC Geriatr. 2019 Jul 22;19(1):195.

37. Newton L, Dickinson C, Gibson G, et al. Exploring the views of GPs, people with dementia and their carers on assistive technology: a qualitative study. BMJ Open. 2016 May 13;6(5):e011132.

38. Boot FH, Owuor J, Dinsmore J, et al. Access to assistive technology for people with intellectual disabilities: a systematic review to identify barriers and facilitators. J Intellect Disabil Res. 2018 Oct;62(10):900-921.

39. Dawe M. Desperately seeking simplicity. Proceedings of the SIGCHI conference on Human Factors in computing systems - CHI '062006. 
40. Kaye HS, Yeager P, Reed M. Disparities in usage of assistive technology among people with disabilities. Assist Technol. 2008 Winter;20(4):194-203.

41. Thordardottir B, Malmgren Fange A, Lethin C, et al. Acceptance and Use of Innovative Assistive Technologies among People with Cognitive Impairment and Their Caregivers: A Systematic Review. Biomed Res Int. 2019;2019:9196729.

42. Klimova B, Valis M, Kuca K. Exploring assistive technology as a potential beneficial intervention tool for people with Alzheimer's disease - a systematic review. Neuropsychiatr Dis Treat. 2018;14:3151-3158.

43. Gutner CA, Galovski T, Bovin MJ, et al. Emergence of Transdiagnostic Treatments for PTSD and Posttraumatic Distress. Current psychiatry reports. 2016;18(10):95-95.

44. Larsson Ranada A, Lidstrom $\mathrm{H}$. Satisfaction with assistive technology device in relation to the service delivery process-A systematic review. Assist Technol. 2019;31(2):82-97.

45. Lachal J, Revah-Levy A, Orri M, et al. Metasynthesis: An Original Method to Synthesize Qualitative Literature in Psychiatry. Frontiers in Psychiatry. 2017;8.

46. Moher D, Liberati A, Tetzlaff J, et al. Preferred Reporting Items for Systematic Reviews and Meta-Analyses: The PRISMA Statement. PLoS Medicine. 2009;6(7):e1000097.

47. Thomas J, Harden A. Methods for the thematic synthesis of qualitative research in systematic reviews. BMC Medical Research Methodology. 2008;8(1):45.

48. Critical Appriasal Skills Programme. CASP Qualitative checklist 2018 [cited 2019 26/11/19]. Available from: https://casp-uk.net/wp-content/uploads/2018/01/CASP-QualitativeChecklist-2018.pdf

49. Adolfsson $\mathrm{P}$, Lindstedt $\mathrm{H}$, Pettersson $\mathrm{I}$, et al. Perception of the influence of environmental factors in the use of electronic planning devices in adults with cognitive disabilities. Disabil Rehabil Assist Technol. 2016 Aug;11(6):493-500.

50. Andregard E, Magnusson L. Experiences of attitudes in Sierra Leone from the perspective of people with poliomyelitis and amputations using orthotics and prosthetics. Disabil Rehabil. 2017 Dec;39(26):2619-2625.

51. Asghar I, Cang S, Yu H. Usability evaluation of assistive technologies through qualitative research focusing on people with mild dementia. Computers in Human Behavior. 2018;79:192-201.

52. Baldwin VN, Powell T, Lorenc L. Factors influencing the uptake of memory compensations: a qualitative analysis. Neuropsychol Rehabil. 2011 Aug;21(4):484-501.

53. Boger J, Quraishi M, Turcotte N, et al. The identification of assistive technologies being used to support the daily occupations of community-dwelling older adults with dementia: a crosssectional pilot study. Disabil Rehabil Assist Technol. 2014 Jan;9(1):17-30.

54. Boot FH, MacLachlan M, Dinsmore J. Are there differences in factors influencing access and continues use of assistive products for people with intellectual disabilities living in group homes? Disabil Rehabil Assist Technol. 2019 Jan 28:1-10.

55. Cook EJ, Randhawa G, Sharp C, et al. Exploring the factors that influence the decision to adopt and engage with an integrated assistive telehealth and telecare service in Cambridgeshire, UK: a nested qualitative study of patient 'users' and 'non-users'. BMC Health Serv Res. 2016 Apr 19;16:137.

56. Creemers $\mathrm{H}$, Beelen $\mathrm{A}$, Grupstra $\mathrm{H}$, et al. The provision of assistive devices and home adaptations to patients with ALS in the Netherlands: patients' perspectives. Amyotroph Lateral Scler Frontotemporal Degener. 2014 Sep;15(5-6):420-5.

57. Darcy S, Maxwell H, Green J. Disability citizenship and independence through mobile technology? A study exploring adoption and use of a mobile technology platform. Disability \& Society. 2016;31(4):497-519.

58. Demain S, Burridge J, Ellis-Hill C, et al. Assistive technologies after stroke: self-management or fending for yourself? A focus group study. BMC Health Serv Res. 2013 Aug 22;13:334. 
59. Dorjbal D, Prodinger B, Zanini C, et al. Living with spinal cord injury in Mongolia: A qualitative study on perceived environmental barriers. J Spinal Cord Med. 2019 Jan 11:1-14.

60. Durham J, Sychareun V, Santisouk P, et al. Users' Satisfaction with Prosthetic and Orthotic Assistive Devices in the Lao People's Democratic Republic: A Cross-sectional Study. Disability, CBR \& Inclusive Development. 2016;27(3):24-44.

61. Elnady A, Mortenson WB, Menon C. Perceptions of Existing Wearable Robotic Devices for Upper Extremity and Suggestions for Their Development: Findings From Therapists and People With Stroke. JMIR Rehabil Assist Technol. 2018 May 15;5(1):e12.

62. Fager SK, Burnfield JM. Patients' experiences with technology during inpatient rehabilitation: opportunities to support independence and therapeutic engagement. Disabil Rehabil Assist Technol. 2014 Mar;9(2):121-7.

63. Fomiatti R, Moir L, Richmond J, et al. The experience of being a motorised mobility scooter user. Disabil Rehabil Assist Technol. 2014 May;9(3):183-7.

64. Gelinas-Bronsard D, Mortenson WB, Ahmed S, et al. Co-construction of an Internet-based intervention for older assistive technology users and their family caregivers: stakeholders' perceptions. Disabil Rehabil Assist Technol. 2019 Aug;14(6):602-611.

65. Gerber E. The Benefits of and Barriers to Computer use for Individuals who are Visually Impaired. Journal of Visual Impairment \& Blindness. 2003;97(9):536-550.

66. Gibson G, Dickinson C, Brittain K, et al. The everyday use of assistive technology by people with dementia and their family carers: a qualitative study. BMC Geriatr. 2015 Jul 24;15:89.

67. Gitlin LN, Luborsky MR, Schemm RL. Emerging concerns of older stroke patients about assistive device use. The Gerontologist. 1998;38(2):169-180.

68. Hedberg-Kristensson E, Ivanoff SD, Iwarsson S. Experiences among older persons using mobility devices. Disabil Rehabil Assist Technol. 2007 Jan;2(1):15-22.

69. Holthe $T$, Jentoft $R$, Arntzen $C$, et al. Benefits and burdens: family caregivers' experiences of assistive technology (AT) in everyday life with persons with young-onset dementia (YOD). Disabil Rehabil Assist Technol. 2018 Nov;13(8):754-762.

70. Holz A, Bennett A, Freethy A, et al. Exploring the Views of Individuals With Chronic Obstructive Pulmonary Disease on the Use of Rollators: A QUALITATIVE STUDY. Journal of Cardiopulmonary Rehabilitation and Prevention. 2018;38(1):49-53.

71. Jamieson $M$, Jack R, O'Neill B, et al. Technology to encourage meaningful activities following brain injury. Disabil Rehabil Assist Technol. 2019 Apr 15:1-14.

72. Lenker JA, Harris $\mathrm{F}$, Taugher $\mathrm{M}$, et al. Consumer perspectives on assistive technology outcomes. Disabil Rehabil Assist Technol. 2013 Sep;8(5):373-80.

73. Mann WC, Tomita M. Perspectives on assistive devices among elderly persons with disabilities. Technology and Disability. 1998;9:119-148.

74. McGrath C, Astell A. The benefits and barriers to technology acquisition: Understanding the decision-making processes of older adults with age-related vision loss (ARVL). British Journal of Occupational Therapy. 2017;80(2):123-131.

75. Mortenson WB, Pysklywec A, Fuhrer MJ, et al. Caregivers' experiences with the selection and use of assistive technology. Disabil Rehabil Assist Technol. 2018 Aug;13(6):562-567.

76. Myburg M, Allan E, Nalder E, et al. Environmental control systems - the experiences of people with spinal cord injury and the implications for prescribers. Disabil Rehabil Assist Technol. 2017 Feb;12(2):128-136.

77. Okonji PE, Ogwezzy DC. Awareness and barriers to adoption of assistive technologies among visually impaired people in Nigeria. Assist Technol. 2019;31(4):209-219.

78. Orellano-Colon EM, Mann WC, Rivero M, et al. Hispanic Older Adult's Perceptions of Personal, Contextual and Technology-Related Barriers for Using Assistive Technology Devices. J Racial Ethn Health Disparities. 2016 Dec;3(4):676-686.

79. Oyesanya TOPRN, Thompson NMPH, Arulselvam KMPH, et al. Technology and TBI: Perspectives of persons with TBI and their family caregivers on technology solutions to 
address health, wellness, and safety concerns. Assistive Technology: The Official Journal Of RESNA. 2019:1-11.

80. Pereira J, Pena C, de Melo M, et al. Facilitators and Barriers to Using Alternative and Augmentative Communication Systems by Aphasic: Therapists Perceptions. 2019 IEEE 32nd International Symposium on Computer-Based Medical Systems (CBMS)2019. p. 349-354.

81. Ravneberg B. Usability and abandonment of assistive technology. Journal of Assistive Technologies. 2012;6(4):259-269.

82. Riikonen $\mathrm{M}$, Paavilainen $\mathrm{E}$, Salo H. Factors supporting the use of technology in daily life of home-living people with dementia. Technology and Disability. 2013;25(4):233-243.

83. Seymour N, Geiger M, Scheffler E. Community-based rehabilitation workers' perspectives of wheelchair provision in Uganda: A qualitative study. Afr J Disabil. 2019;8:432.

84. Smith R, Quine S, Anderson J, et al. Assistive devices: self-reported use by older people in Victoria. Australian Health Review. 2002;25(4):169-177.

85. Taherian S, Davies C. Multiple stakeholder perceptions of assistive technology for individuals with cerebral palsy in New Zealand. Disabil Rehabil Assist Technol. 2018 Oct;13(7):648-657.

86. Van Den Heuvel E, Jowitt F, McIntyre A. Awareness, requirements and barriers to use of Assistive Technology designed to enable independence of people suffering from Dementia (ATD). Technology and Disability. 2012;24(2):139-148.

87. Weerasinghe IE, Fonseka P, Dharmaratne $\mathrm{S}$, et al. Barriers in Using Assistive Devices among a Group of Community-dwelling Persons with Lower Limb Disabilities in Sri Lanka. Disability, CBR \& Inclusive Development. 2015;26(1).

88. Berkun S. Programmers, designers, and the Brooklyn bridge. 2004 [cited 2020 1st March]. Available from: https://scottberkun.com/essays/30-programmers-designers-and-thebrooklyn-bridge/

89. Orpwood RD. Design methodology for aids for the disabled. Journal of Medical Engineering \& Technology. 1990 1990/01/01;14(1):2-10.

90. Orpwood R, Bjørneby S, Hagen I, et al. User involvement in dementia product development. Dementia: The International Journal of Social Research and Practice. 2004;3(3):263-279.

91. Gibson G, Dickinson C, Brittain K, et al. Personalisation, customisation and bricolage: how people with dementia and their families make assistive technology work for them. Ageing and Society. 2019;39(11):2502-2519.

92. Greenhalgh T, Procter R, Wherton J, et al. What is quality in assisted living technology? The ARCHIE framework for effective telehealth and telecare services. BMC Medicine. 2015 2015/04/23;13(1):91.

93. Pols J, Willems D. Innovation and evaluation: taming and unleashing telecare technology. Sociology of Health \& Illness. 2011;33(3):484-498.

94. López Gómez D. Little arrangements that matter. Rethinking autonomy-enabling innovations for later life. Technological Forecasting and Social Change. 2015 2015/04/01/;93:91-101.

95. Greenhalgh T, Wherton J, Sugarhood P, et al. What matters to older people with assisted living needs? A phenomenological analysis of the use and non-use of telehealth and telecare. Social Science \& Medicine. 2013 2013/09/01/;93:86-94.

96. Büscher M, Gill S, Mogensen P, et al. Landscapes of Practice: Bricolage as a Method for Situated Design. Computer Supported Cooperative Work (CSCW). 2001 2001/03/01;10(1):128.

97. Hartswood M, Procter R, Rouncefield M, et al., editors. Being there and doing IT in the workplace: A case study of a co-development approach in healthcare2000.

98. Parette $\mathrm{P}$, Scherer M. Assistive Technology Use and Stigma. Education and Training in Developmental Disabilities. 2004;39(3):217-226.

99. Arboleda-Flórez J. What causes stigma? World psychiatry : official journal of the World Psychiatric Association (WPA). 2002;1(1):25-26. 
100. Cioffi D. The looking-glass self revisited: Behavior choice and self-perception in the social token. The social psychology of stigma. New York, NY, US: Guilford Press; 2000. p. 184-219.

101. Kwasnicka D, Dombrowski SU, White M, et al. Theoretical explanations for maintenance of behaviour change: a systematic review of behaviour theories. Health Psychology Review. 2016 2016/07/02;10(3):277-296.

102. Dourish P. What we talk about when we talk about context. Personal and Ubiquitous Computing. 2004 2004/02/01;8(1):19-30.

103. Wherton J, Sugarhood P, Procter R, et al. Co-production in practice: how people with assisted living needs can help design and evolve technologies and services. Implementation Science. 2015 2015/05/26;10(1):75.

104. Realpe A, Wallace LM. What is co-production? 2010.

105. Pope C. Resisting Evidence: The Study of Evidence-Based Medicine as a Contemporary Social Movement. Health. 2003;7(3):267-282.

106. Wieringa S, Engebretsen E, Heggen $\mathrm{K}$, et al. Has evidence-based medicine ever been modern? A Latour-inspired understanding of a changing EBM. J Eval Clin Pract. 2017 Oct;23(5):964-970.

107. Ioannidis JPA. Why Most Published Research Findings Are False. PLOS Medicine. 2005;2(8):e124.

108. Greenhalgh T. Why Do We Always End Up Here? Evidence-Based Medicine's Conceptual CulDe-Sacs and Some Off-Road Alternative Routes. Journal of primary health care. 2012 06/07;4:92-7.

109. Greenhalgh T, Howick J, Maskrey N. Evidence based medicine: a movement in crisis? BMJ : British Medical Journal. 2014;348:g3725.

110. Mol A. The Logic of Care: Health and the Problem of Patient choice. London: Routledge; 2008.

111. Hinder S, Greenhalgh T. "This does my head in". Ethnographic study of self-management by people with diabetes. BMC Health Services Research. 2012 2012/03/29;12(1):83.

112. Ruston A, Smith, Fernando. Chronic illness, self-management and technology: type 1 diabetes patients' views of the use of technology to communicate with health professionals about their disease. Patient Intelligence. 2012 11/01;4:71.

113. Dougherty D. The maker movement. Innovations: Technology, governance, globalization. 2012;7(3):11-14. 